\title{
Human Capital and the Use of Time
}

by

\section{Frank Jones}

No. 79

Family and Community Support Systems Division, Statistics Canada

R.H. Coats Building, Ottawa, K1A OT6

Phone: (613) 951-1931

July 1995

This paper represents the views of the authors and does not necessary reflect the opinions of the Statistics Canada Bureau. 



\begin{abstract}
The key hypothesis of this paper is that time use data bases make possible a broader view of the benefits and costs of human capital than is otherwise possible. This achievement is enabled by a set of integrated information on not only educational attainment but also on time devoted to formal and informal study, to paid and unpaid work of economic value, to work of civic value, to leisure activities, and to the educating of children by parents. It is argued that such information is central to human capital theory, though much of it, especially on the leisure costs of investment in human capital, has been hitherto ignored. This new information is important because it can be used to inform the debate over the key issues in this field -- for example, the value of increased public support to formal education -- by measuring previously overlooked aspects of the benefits and costs of investment in human capital.
\end{abstract}

Keywords: Human Capital, Time Use, Investment in Human Capital - Benefits, Investment in Human Capital - Costs 



\section{Introduction}

If it is true that "Growth is the only evidence of life" (J. H. Newman) then all learning experiences throughout a lifetime are important events, worthy of attention by not only educators, including parents, but also social scientists, policy analysts and statisticians. This importance of the subject may account for the vast literature on education and on the stocks and flows of human capital. For the economist, an impressive collection of articles on the economics of education has been assembled by George Psacharopoulos. In his review of this book, Mark Blaug sees it as a primary source, and points out some limitations, while noting that the literature has not advanced much from the 1960s. ${ }^{1}$

There does not appear to be one central problem with human capital theory and evidence, but rather many small ones. Some have important policy implications. The problems with the theory originate in part in the concept of human capital itself. There are also problems with the conceptualization and measurement of the benefits and costs of Investment in Human Capital, (IHC). The concept of IHC has been developed by analogy to that of physical capital. Briefly, IHC is any activity that raises the productive capacity of manpower. ${ }^{2}$ The activities usually considered to be productive are market sector activities, or the activities of paid labour as distinct from unpaid labour, perhaps because economists have tended to ignore the economic value of unpaid work. The acquisition of informal education is not typically regarded as a part of IHC. The discussions of Machlup and Covey ${ }^{3}$, however, suggests that it should be. Concerning measures of IHC, very few have actually set out to measure informal IHC. Juster might be considered an exception, though some of his assumptions, especially those involving the investment component of leisure time, seem unrealistic. ${ }^{4}$ Also, his concept of investment time would seem to be wider than that of human capital, and formal and informal IHC are not distinguished.

On the subject of the results of IHC, the benefits are much more fully studied than the costs. Perhaps the most comprehensive treatment of benefits appear in two articles in The Economics of Education, and an article by Haveman and Wolfe. ${ }^{5}$ The personal costs of acquiring education are not nearly so well treated. Specifically, they ignore the impacts on leisure, and on paid and unpaid work, and assume the main cost is foregone income.

The basic assumption of this paper is that by viewing the problems from the perspective of how people use time, some of the problems can be resolved, at least in part. The reason is that

\footnotetext{
${ }^{1}$ Mark Blaug, "Review of Economics of Education: Research and Studies, edited by George Psacharopoulos, Pergamon Books: Oxford, 1987", in The Journal of Human Resources, XXIV, no.2, Spring, 1989, pp. 331-5.

${ }^{2}$ M. Woodall, "Economics of Education: A Review", in George Psacharopoulos, ed., Economics of Education: Research and Studies, 1987, p. 1.

${ }^{3}$ Stephen R. Covey, The Seven Habits of Highly Effective People, Simon and Schuster: New York, 1989, (habit seven); and F. Machlup, "Knowledge Industries and Knowledge Occupations," in George Psacharopoulos, ed., Economics of Education: Research and Studies, 1987, pp. 14-21.

${ }^{4}$ Refer to footnote 13.

${ }^{5}$ Robert H. Haveman and Barbara L. Wolfe, "Schooling and Economic Well-Being: The Role of Nonmarket Effects", Journal of Human Resources, XIX, no. 3, Summer, 1984, pp. 377-407.
} 
it is possible to identify the activities comprising IHC, to measure their time duration, and to relate such a measure of IHC to the duration of time spent in other activities that are fundamentally important, and to the roles, responsibilities and stock of human capital of individuals. In the following a problem area is first reviewed, then the added insight of the time use perspective is discussed, and finally some estimates are presented. These estimates use, wherever possible, the concepts, measures and relationships that are being considered as part of the Total Work Account System ${ }^{6}$ (TWAS) of Statistics Canada. Three problem areas are considered in turn: the concept and measure of IHC, the benefits of such investment, and their costs. The controversial issues associated with the valuing of time are ignored.

\section{Human Capital Concepts}

M. Woodhall ${ }^{7}$ notes that many economists believe that "education and training create assets in the form of knowledge and skills which increase the productive capacity of manpower in just the same way as investment in new machinery raises the productive capacity of the stock of physical capital". He adds that the concept applies to any activity "which increases the quality and productivity of the labour force", and mentions expenditures on health care and migration as examples $^{8}$. By extending the concept to health and migration activities, a theoretical problem is opened up. The problem revolves around the lumping together of very different activities, each of which may be expected to raise productivity in different ways and using very different mechanisms. This consideration argues for the exclusion of health and migration activities from the theoretical definition of human capital, or at least to treat them as separate and different forms of human capital. In this study the focus is only on education and training; this is a big enough research challenge in itself.

When confined to education, however, the definition of human capital should not be as narrow as some economists take it. Lockheed, for example, reviews a number of articles on the impact of farmer's education on farm output and in all cases the variable used is really schooling, not education ${ }^{9}$. Whether or not the operator grew up on a farm and thus acquired skills, experience and tacit knowledge just by observing, or by a slow process of practice and osmosis, does not seem to have been considered an important factor in these studies, nor have other indicators of informal education been used in these studies. Similarly, there is a vast literature by economists on school production functions ${ }^{10}$, but none on the processes of informal education, though family background is known to have a major impact on success in school. The relative

\footnotetext{
${ }^{6}$ Leroy O. Stone, Marie-Therese Chicha and Frank Jones, Design of the Statistics Canada Total Work Accounts System, paper presented to the 23rd conference of the International Association for Research on Income and Wealth, St. Andrews, New Brunswick, Canada, August 21 to 27, 1994.

${ }^{7}$ M. Woodall, "Economics of Education: A Review", in George Psacharopoulos, ed., Economics of Education: Research and Studies, 1987, p. 1.

${ }^{8}$ Ibid. pp.1-2.

${ }^{9}$ M. E. Lockheed, "Farmer's Education and Economic Performance", in G. Psacharopoulos, ed., Economics of Education: Research and Studies, 1987, pp. 110-116.

${ }^{10}$ A survey is given by E. A. Hanushek, "Educational Production Functions", In George Psacharopoulos, Economics of Education, 1987, pp. 33-42.
} 
importance of informal education is also suggested by a consideration of the four types of useful knowledge discussed by Machlup: practical, intellectual, pastime and spiritual knowledge. Of these, only intellectual knowledge is increased more by schooling than by informal education ${ }^{11}$. Informal education occurs not only in the home but also in many types of voluntary associations and self-help groups. In view of the importance of informal education, and its direct and indirect influences on both formal education, paid, and unpaid work, it is proposed that it be measured separately and not ignored in analytical work.

\section{Measures of Formal and Informal IHC}

Schooling, or formal IHC comprises time spent in classes for either full-time or part-time credit courses, and course homework connected with such classes. Time use surveys are an important source of information on formal education, because of the importance to success in the formal educational system of two characteristics missed in most surveys, part-time schooling and homework. According to this definition formal IHC in 1992 averaged 35 minutes a day for the population 15 and over, 36 by men and 34 by women; most of the formal education was undertaken by those aged 15-19 and 20-24 -- Charts 1a and b. Students committing three hours or more a day, named full-day students, averaged six hours a day, while students putting in at least some time on formal education but less than three hours, part-day students, worked an average of 1.5 hours a day. Full-day students, according to this three hour plus definition, numbered 731 thousand men and 726 thousand women. The part-day students were fewer than half, 207 thousand men and 322 thousand women.

By age group, the full-day students are most heavily concentrated in the 15-19 group, followed by the 20-24 age group; full-day study is relatively rare in the older age groups.

The best source of information on informal education is the time use surveys which code such activities as special lectures, self study, self-help group involvement -- for most of this activity is designed to overcome functional limitations -- and those activities connected with the learning and renewing of values and behaviours needed for effective functioning, communication and work. ${ }^{12}$ Such activities may be assumed to improve the quality and productive capacity of both paid and unpaid work. But many other activities educate too. For example, much time spent watching television, reading books, and attending cultural events or attractions is educational. Because most of the value of these activities is recreational, however, these activities are classified as leisure in the proposed taxonomy. ${ }^{13}$ Even conversation can be educational. Joseph

\footnotetext{
${ }^{11}$ F. Machlup, "Knowledge Industries and Knowledge Occupations", in George Psacharopoulos, ed., Economics of Education, 1987, pp. 15-16.

${ }^{12}$ This point is emphasized in The Seven Habits of Highly Effective People, 1989, By Stephen R. Covey; it is habit seven, "Sharpen the Saw".

${ }^{13}$ An alternative approach is to decide on the proportion of each recreational activity that is geared to providing future satisfactions, and call this the investment component of the time. F. Thomas Juster uses this method. In his "Investments of Time by Men and Women", (In time Goods and Well-Being, 1985, page 186), he includes as investment time all of participation in professional or union time; a half of the time spent participating in fraternal, civic, volunteer, religious and various other organizations, attending lectures as non-students, and hobbies; threetenths of time spent in quiet games, reading and letter-writing; and two-tenths of time spent listening to the radio or to music, attending the theatre or films, visiting museums, relaxing, thinking, and planning. He does not define the activities that make up informal education, though those mentioned in this note would appear to be examples.
} 
Howe once said "The best of colleges -- a farmer's fireside". ${ }^{14}$ This quote suggests that the definition of activities comprising informal education is not easy to come by, though in this case it is proposed to classify conversation as leisure activity, because the educational value of it is unknown, though probably relatively insignificant compared to its recreational or leisure value.

Quantitatively, informal education is far less important than formal education. The average commitment over all adults is just over six minutes a day, five by men and seven by women -- Chart 1d. It is almost double the average in the older age groups, 50-64 and 65 and over -- Chart 1c. The part-day formal education students spend an average of 15 minutes a day, compared to only six by non-students, and four by part-day formal students.

\section{Benefits of Human Capital}

The IHC literature stresses private and social benefits of education delivered by schools. ${ }^{15}$ Hanushek provides a good summary of many other benefits of formal education:

Although the relationship of schooling and labour market performance is central to many policy questions, it [the literature] also examined the role of education in increasing job satisfaction, in maintaining personal health, and in increasing the productivity of mothers engaged in household production, as well as the effects of the mother's education on the learning of young children. Further, political scientists have considered the effect of education on political socialization and voting behaviour, and sociologists have considered the relationship between education and criminality. ${ }^{16}$

But there are other benefits as well. Consumption benefits are real for many, though are hard to measure. ${ }^{17}$ They show up in such forms as higher quality leisure ${ }^{18}$ and improved decision making. Finally, there are other hard-to-measure benefits which arise from having a well-informed and responsible citizenry; they may improve the economy not only through better government but also by fostering public order and better communication on the need for and value of public goods.

${ }^{14}$ Quoted in G. M. Grant, Joseph Howe, 1906, p. 33.

15 Solmon discusses institutional benefits as well: see L.C. Solmon, "The Range of Educational Benefits", in George Psacharopoulos, ed., Economics of Education: Research and Studies, Pergamon Books: Oxford, 1987, pp. 83-93.

16 See E. A. Hanushek, "Educational Production Functions," in G. Psacharopoulos, ed., Economics of Education, 1987, p. 34.

${ }^{17}$ Edward T. Gullason, "The Consumption Value of Schooling: An Empirical Estimate of One Aspect," Journal of Human Resources, XXIV, 2, pp. 287-98, Spring, 1989, writes "A great deal of consumption value is associated with one particular form of human capital -- a college education. Many college experiences yield consumption value. These include learning experiences associated with classroom instruction, enjoying on-campus events, such as dances, lectures and concerts; and any other social or academic experience that yields satisfaction to the individual as the process of schooling is undertaken." p. 288.

${ }^{18}$ Higher quality in the sense of an expanded feasible set of enjoyable activities, and a better choice of activities, one that takes into account not only the present enjoyment but also the "morning after" effects. 
H. R. Bowen, gives excellent descriptions of the private and social benefits of college and university education. ${ }^{19}$ There are several assertions in Bowen's description that may be rephrased as hypotheses, and many more that can not be tested easily. The testable hypotheses are as follows.

1. Higher education promotes participation in sports and cultural activities.

2. Higher education promotes participation in community work or work of civic value.

3. Higher education increases the chances of labour force participation.

4. Higher education increases the chances of finding work.

5. People with higher education work longer hours than those with less education.

6. Parents with higher education spend more time in the careful rearing and education of their children than parents with less education.

To test such hypotheses it would be necessary to control for many possible influences. Also, the hypotheses would seem applicable to the behaviour not only of college graduates, as compared with non-graduates, but also to the behaviour of those with some college, or high school graduation, as compared with those with less education.

Informal education in the form of self study, non-credit lectures and courses are examples of characteristics that have not received attention in the literature, possibly because of the unavailability of data on the subject, but also because public policies are not directly implicated. The benefits of informal education can be big, however, even when compared to those of formal education. The relative strength of informal over formal education is in the area of instilling values, skills and habits important for the general business of working and living well with others, and in overcoming physical, emotional or personal handicaps, ranging from alcoholism to fear of public speaking and overcoming personal loss.

Formal and informal education are related. For example, a reduction in teaching time may decrease the workload of the educator but increase the study needed by the student, or help provided by parents. Also, help with homework and counsel on the benefits of education by parents can boost performance in school.

\section{Evidence on the Benefits of Education}

The benefits described above suggest a systematic relationship between the level of formal education and quantity of paid work, work of civic value, child care and child nurture, investment in human capital and many kinds of leisure. A basic table, showing the level of education as columns and types of work and leisure as rows, shows these relationships. The time use data base enables the effect of educational attainment on work and leisure, while controlling for the influence of such variables as age, sex, living arrangement, health status, and other variables.

\footnotetext{
${ }^{19}$ H.R. Bowen, Investment in Learning: the Individual and Social Value of American Higher Education, Jossey Bass: San Francisco, 1977, quoted by Solmon, op. cit., pp.92-93.
} 
Looking at the overall relationship between educational attainment and work, study and leisure, the following patterns are clear (they are illustrated in Charts 2 and 3 ).

1. The total work intensity, paid plus unpaid work and associated commuting ${ }^{20}$, rises strongly with educational attainment for both men and women -- Chart 2A. It is assumed that work is a valued personal good, partly because it is normally freely chosen, though obviously the overwork of a "workaholic" would be one exception.

2. This relationship appears to be owing to the strong positive relationship between paid work and educational attainment -- Chart 2B: unpaid work appears to have no linear relationship with educational attainment since work increases, then falls with education -Chart 2C.

3. Work of civic value, (defined and explained in the appendix) though consuming relatively few minutes a day, also tends to rise with educational attainment, especially for women -Chart 2D.

4. Overall leisure tends to fall with educational attainment suggesting that the increased work commitments are made at the expense of leisure -- Chart 3A.

5. The active leisure component tends to decrease with educational attainment, Chart 3B, while passive leisure decreases even more strongly and consistently with educational attainment -- Chart 3C.

6. The duration of sleep also tends to decrease with educational attainment: for example, women with university or trade (or community college) degrees sleep over half an hour less than women with only elementary school education -- Chart 3D.

Some of these results may merely reflect the fact that those with higher education tend to be younger or have taken on more family or other responsibilities. The data base allows one to explore such possible relationships.

The data base may also be applied to explore the relationship between educational attainment and the quantity and type of time spent with children by mothers and fathers. ${ }^{21}$ Parents are found to have a pattern of time use that allocates considerable time to child care and nurture, and to other time spent with children. Division of labour both inside and outside the home means that the time use patterns of mothers and fathers differ significantly. A strong positive association of time spent teaching and nurturing children is evident in Chart $4 \mathrm{~B}$, together with the much greater commitment of mothers than fathers to this important role. The positive association with child care is also evident in Chart $4 \mathrm{C}$, though the commitment falls off a little for

\footnotetext{
${ }^{20}$ The concepts of total work intensity (or work load) and paid unpaid work are those in the Total Work Account System of Statistics Canada -- refer to Leroy O. Stone, et al., op. cit., 1994, pp. 13-14.

${ }^{21}$ Important articles on this subject include Arleen Leibowitz, "Human Investments in Children", Journal of Political Economy, March-April, 1974, pp. S111-S131; and C. Russell Hill and Frank P. Stafford, "Parental Care of Children: Time Diary Estimates of Quantity, Predictability, and Variety", in F. Thomas Juster and Frank P. Stafford, eds., Time, Goods and Well-Being, University of Michigan: Ann Arbor, 1985, pp. 415-437.
} 
both mothers and fathers who hold a university degree. In contrast the total time spent with children shows no clear association with educational attainment, though the time per child may be greater because more highly educated mothers have fewer children. ${ }^{22}$ The work of civic value by mothers and fathers is portrayed in chart 4A, to see if it is much less than that of all adults, whose commitment is displayed in chart 2D. The time commitment is not much less, and still shows the general positive association with educational attainment.

\section{Costs of Investment in Human Capital (IHC)}

In the IHC literature the cost of education comprises the total resources devoted to education, including the opportunity cost of the student time, measured usually in terms of income foregone or lost because of studying rather than working. The lost income is the cost to the full-time or part-time student; whether the student is affiliated with the formal education system or is involved in informal learning does not matter. The loss of output that the student could have produced is the resource cost to the economy as a whole.

There are several limitations in this conception of costs. First it is normally assumed that the lost output is that produced by paid work, though obviously unpaid work of economic value can suffer too, and some of the work lost may be very important to effective and quality home making and child rearing. Second, it is assumed in the literature, usually implicitly, that student time detracts totally from paid work time, though it is more reasonable to assume that the lost work will not be quite as much as the extra learning time. Volunteer work, work of civic value, passive and active leisure, sleep or other time may suffer too. And each of these activities yield utility.

A key cost ignored in the literature is the lost leisure occasioned by education and study. The 88 articles by economists in the 1985 Encyclopedia of Education ${ }^{23}$ contain no articles on this subject. It is interesting to note that while the literature has given some attention to consumption benefits of education, especially college education, it is relatively silent on the question of costs, a subject of which any student is fully aware. H. L. Mencken makes the point well by overstating it: "School days, I believe are the unhappiest in the whole span of human existence. They are full of dull, unintelligible tasks, new and unpleasant ordinances, brutal violence of common sense and common decency." ${ }^{24}$ According to Aristotle "The roots of education are bitter, but the fruit is sweet." 25 Such costs of education may not seem measurable, but actually we can estimate the impact of educational activities on leisure and other uses of time. And the preliminary estimates indicate that these costs are substantial.

\footnotetext{
${ }^{22}$ The findings reported here are consistent with those in C. Russell Hill and Frank P. Stafford, "Parental Care of Children: Time Diary Estimates of Quantity, Predictability, and Variety", in F. Thomas Juster and Frank P. Stafford, eds., Time, Goods and Well-Being, University of Michigan: Ann Arbor, 1985, pp. 415-437.

${ }^{23}$ Gathered together in George Psacharopoulos, ed., Economics of Education, 1987.

24 "Travail", The Baltimore Evening Sun, October 8, 1928.

25 4th c. B.C., quoted in Diogenes Laertius' Lives and Opinions of Eminent Philosophers, 3rd c. A.D., tr. R.D. Hicks.
} 


\section{Evidence on the Costs of Investing in Human Capital}

The major costs of acquiring education are the work -- paid, unpaid, and work of civic value -- and leisure foregone. These costs may be displayed in a table that shows the average time allocated to categories of work and leisure by full-day, part-day students, and by nonstudents. The trade-offs are expected to vary by many factors, though a basic one is age group, since the transition years of the older teens and early twenties involve relatively heavy investments in formal education. Behaviour is also expected to be very different on the weekends than on weekdays, because of the concentration of leisure on weekends and work and formal education on weekdays. Only the results that are highly significant in a statistical and theoretical sense are summarized below: the only insignificant results have to do with the impact of education on work of civic value.

One way to measure the time costs of education is to estimate the trade-offs using a regression equation, in which the minutes a day of work or leisure is the dependent variable, and formal and informal education are independent variables. The coefficient estimated for the minutes of formal education gives the estimated lost minutes (or hours) of work resulting from a one minute (or hour) increase in study time, under the assumption that the time commitment to selected other activities in the model does not change.

Regressions (details results not shown) yield the following results. Among older teens 15-19 years old a one hour increase in formal IHC on weekdays prompts a half hour decrease in actual paid work. On weekends the cutback is also half an hour. For those 20-24 the weekday decrease in actual paid work occasioned by a one hour increase in formal education is .63 hours, and .75 hours on the weekend. An hour of informal IHC on the weekend prompts a half hour reduction in actual paid work of older teens, and a 1.3 hour reduction in the paid work of young adults. Weekday investments in informal education are temporally insignificant.

Time spent on formal education also negatively impacts on passive, active and other leisure -- the results of the regressions predicting minutes a day of active leisure are displayed in table 1, below. For the 15-19 year olds, the proportions of an hour of passive, active and other leisure time given up, on weekdays, are $.43, .42$ and .48, respectively. On weekends the cutbacks are about the same, except for a higher (.72) decrease in active leisure. Young adults 20-24 give up less active but more passive and other leisure on weekdays for an hour increase in formal education, .51, .36, and .76 of an hour, respectively, for passive, active and other leisure. On the other hand, they give up much less leisure on the weekend: $.34, .45$, and .51 of an hour for these three types of leisure.

Unpaid work of economic value also suffers as a result of acquiring formal education. Among older teens, the decrease on weekdays and weekends is .4 of an hour, just slightly less than the reduction by young adults 20-24. Informal education also results in a decrease in unpaid work, though the impacts are significant only on the weekends. For older teens an increase of one hour of informal education prompts a .4 hour reduction of unpaid work. For young adults the impact is 1.1 meaning that an increase in one hour of informal education is accompanied by a completely offsetting decrease in unpaid work. 
Table 1.

Summary of OLS Regression Results, Where the Dependent Variable is Minutes a Day of Active Leisure, by Subpopulation, 1992

\begin{tabular}{|c|c|c|c|c|}
\hline & \multicolumn{2}{|c|}{ Older teens, $15-19$} & \multicolumn{2}{|c|}{ Young adults, 20-24 } \\
\hline & weekdays & weekend days & weekdays & weekend days \\
\hline $\mathrm{R}$ square & .478 & .530 & .396 & .417 \\
\hline Mean, minutes/day & 88.5 & 146.8 & 59.3 & 76.3 \\
\hline $\begin{array}{l}\text { Intercept } \\
\text { b coefficients: }\end{array}$ & 428 & 484 & 369 & 371 \\
\hline Formal study & -.42 & -.72 & -.36 & -.45 \\
\hline Informal study & -.57 & -.32 & -.27 & -.01 \\
\hline Work of civic value & -.53 & .59 & -.54 & -.41 \\
\hline Actual paid work & -.50 & -.62 & -.43 & -.43 \\
\hline Unpaid work & -.57 & -.58 & -.46 & -.40 \\
\hline Passive leisure & -.53 & -.61 & -.47 & -.51 \\
\hline Other leisure & -.44 & -.43 & -.35 & -.30 \\
\hline
\end{tabular}

Note: The $b$ coefficient is an estimate of the minutes a day of active leisure (dependent variable) lost as a result of involvement in the activity to which the coefficient belongs, given other activities are held constant. All coefficients are highly significant except the b coefficients for work of civic value and informal study.

These regression results are consistent with basic tabulations of time uses by student status. In charts 5 and 6 full-day students are defined as those putting in three or more hours a day of formal education, learning and study, on the diary day, and part-day students as those spending less than three hours. Non-students spend no time on formal education and constitute by far the majority of adults.

A strong and consistent relationship between student status and most of the categories of work and leisure is evident in most of the charts. For example full-day students put in substantially less time than part-day and non-students into total work intensity (paid plus unpaid work, plus commuting), Chart 5A, actual paid work, Chart 5B, unpaid work of economic value, Chart 5C, work of civic value, Chart 5D, and child nurture, Chart 5E. These charts also show that full-day students, however, still put in substantial quantities of paid and unpaid work despite their strong commitments to formal education. Chart 6 shows some aspects of the leisure costs that go with being either a full-day or part-day student. The clearest indication of lost leisure associated with being a full-day or part-day student is evident in the total leisure time Chart 6A, passive leisure time, Chart $6 \mathrm{C}$, time spent socializing, Chart $6 \mathrm{E}$, and watching television, listening to the radio, records, tapes or $\mathrm{CDs}$, Chart $6 \mathrm{~F}$. There are only two significant exceptions to the overall patterns. First, male part-day students spend much more time than either men who do not study at all, or especially, male full-day students -- Chart 5B. And second, both male and female part-day students sleep longer on average than either their non-student, or especially full-day student counterparts -- Chart 6D. 


\section{Conclusion}

To summarize, it is proposed that very basic concepts in human capital theory be refined. First, it should be recognized that the concept of human capital comprises diverse activities ranging from education to health and migration, and this causes theoretical problems. Concerning the education component, this needs to be interpreted more broadly than comprising only formal education, though a distinction needs to be maintained between formal and informal education. Secondly, it is proposed that informal education be integrated into human capital theory; a definition and measure of it is offered. And finally, the concepts and measures have to be used with full recognition of their weaknesses.

On the benefits side, several relationships between educational attainment and other important variables are found. Paid work hours, work of civic value, and time devoted to child care and nurture are examples of important time uses that increase with the level of educational attainment. On the other hand, leisure time, especially passive leisure, and the duration of sleep tends to decrease with educational attainment.

Concerning the costs of IHC, it is shown that an increase in study time results in cutbacks in both leisure and work activities. This behaviour is typical of all of the subpopulations studied. The quantity of work given up, however, is never so great as to be equivalent to extra study taken on, as seems to be assumed in much of the literature on IHC.

It is possible that human capital theory will advance only after a fundamental redesign of basic concepts and measures so that new relationships may be defined and old ones refined. The benefits and costs of education explored in this paper illustrate the kind of refinements and developments of some aspects of the theory of human capital enabled by new concepts and relationships concerning the way people use time. 


\section{APPENDIX}

\section{Work of Civic Value}

Work of Civic Value (WCV) is any activity carried out by an individual that is deemed to be part of one's civic responsibilities, such as voting, attending political meetings, cleaning up the environment either alone or as part of a group or association, writing a letter to one's member of parliament, attending a planning meeting at one's church or neighbourhood association, sitting as a board member of a voluntary association, or taking one's children to a cultural event. More formally, WCV is unpaid non-investment activity undertaken by an individual that, by its nature, is thought to yield more public, community or societal benefits than private or family benefits. This means that taking formal courses is not deemed to be WCV (this is an investment in human capital that will yield a stream of civic and private benefits in the future), nor is attending a worship service (because private and investment benefits predominate), nor is attending an opera (because the private benefits are assumed to predominate); though taking one's children to worship, to the opera or to a museum is deemed to be WCV.

Unlike work of economic value, an equivalent activity in the market or government sectors is not always easily found, and in some cases does not exist at all. Though such activities are thought to be essential to the promotion of peace, order and good government; effective and just local communities; more publicly sensitive schools, hospitals, businesses and other institutions; and civic minded and environmentally sensitive citizens. It is only by quantifying the civic contributions of citizens that the value of basic institutions such as the family, school, faith community and voluntary associations will be more fully appreciated. 


\section{Chart 1}

Average Minutes a Day of Formal and Informal Education, by Age and Sex, 1992

A. Formal Education

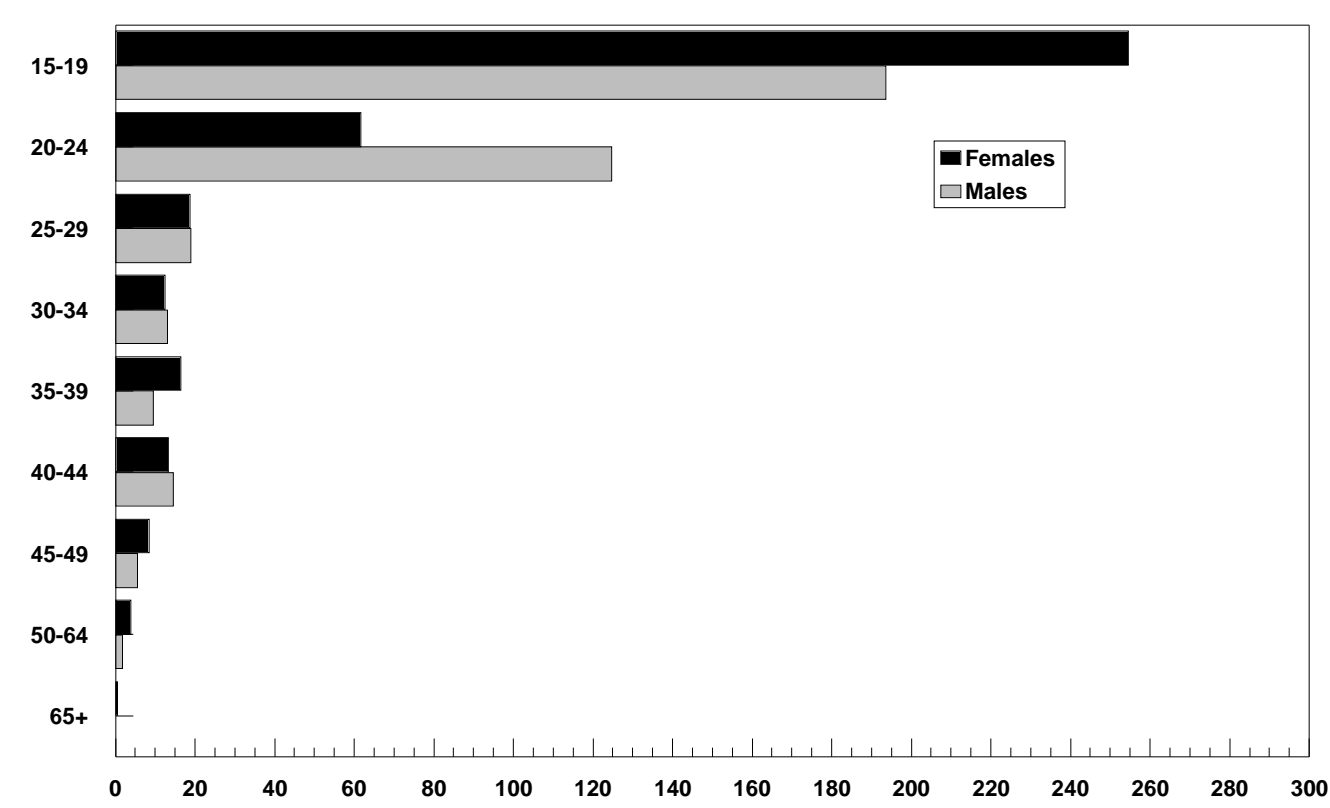

B. Formal Education

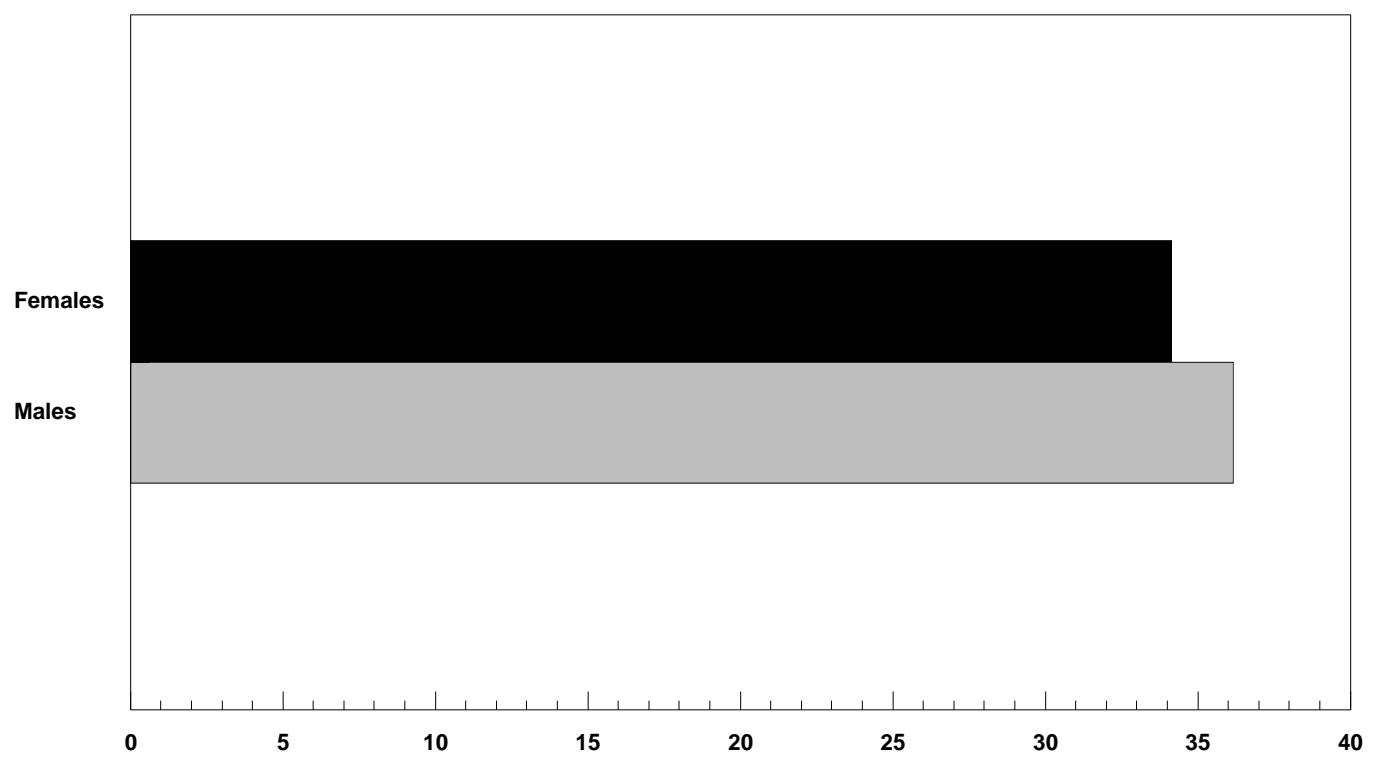




\section{Chart 1}

Average Minutes a Day of Formal and Informal Education, by Age and Sex, 1992

\section{Informal Education}

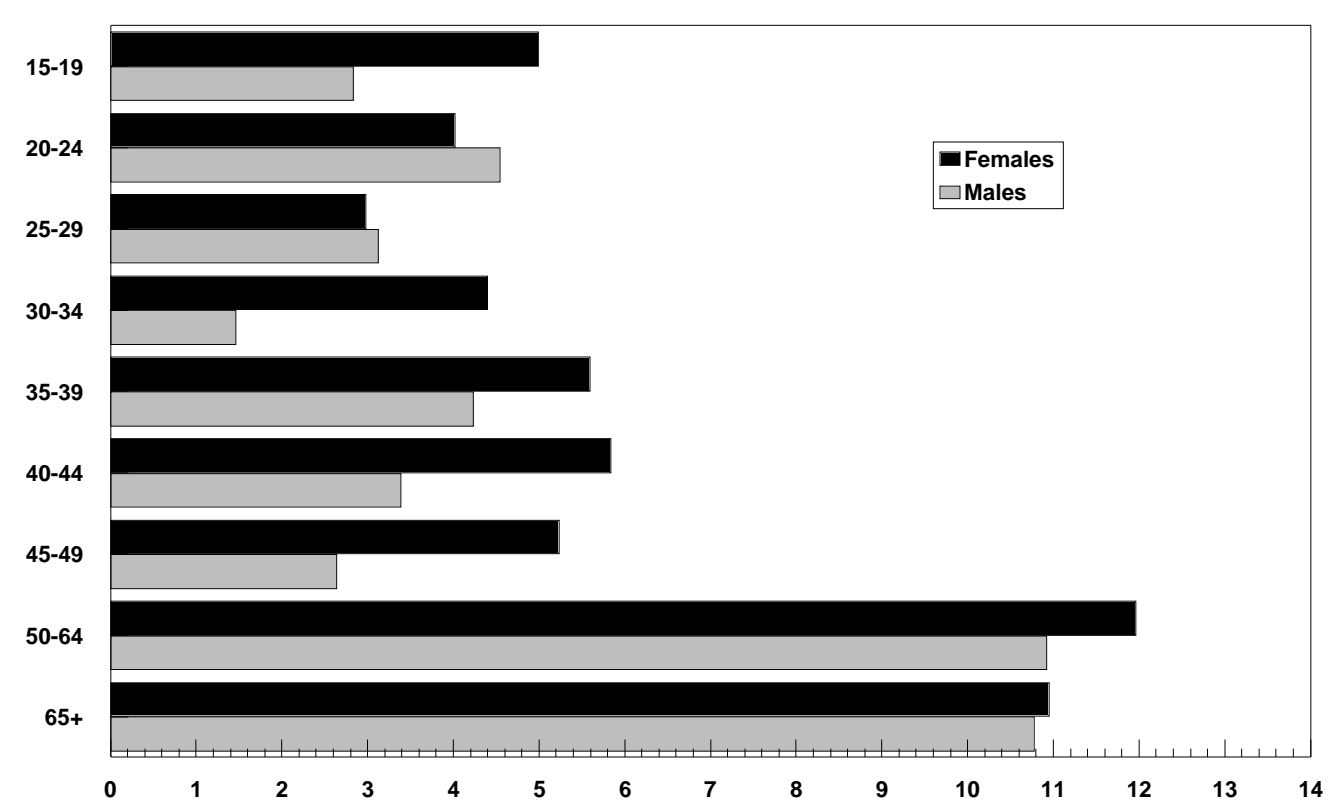

D. Informal Education

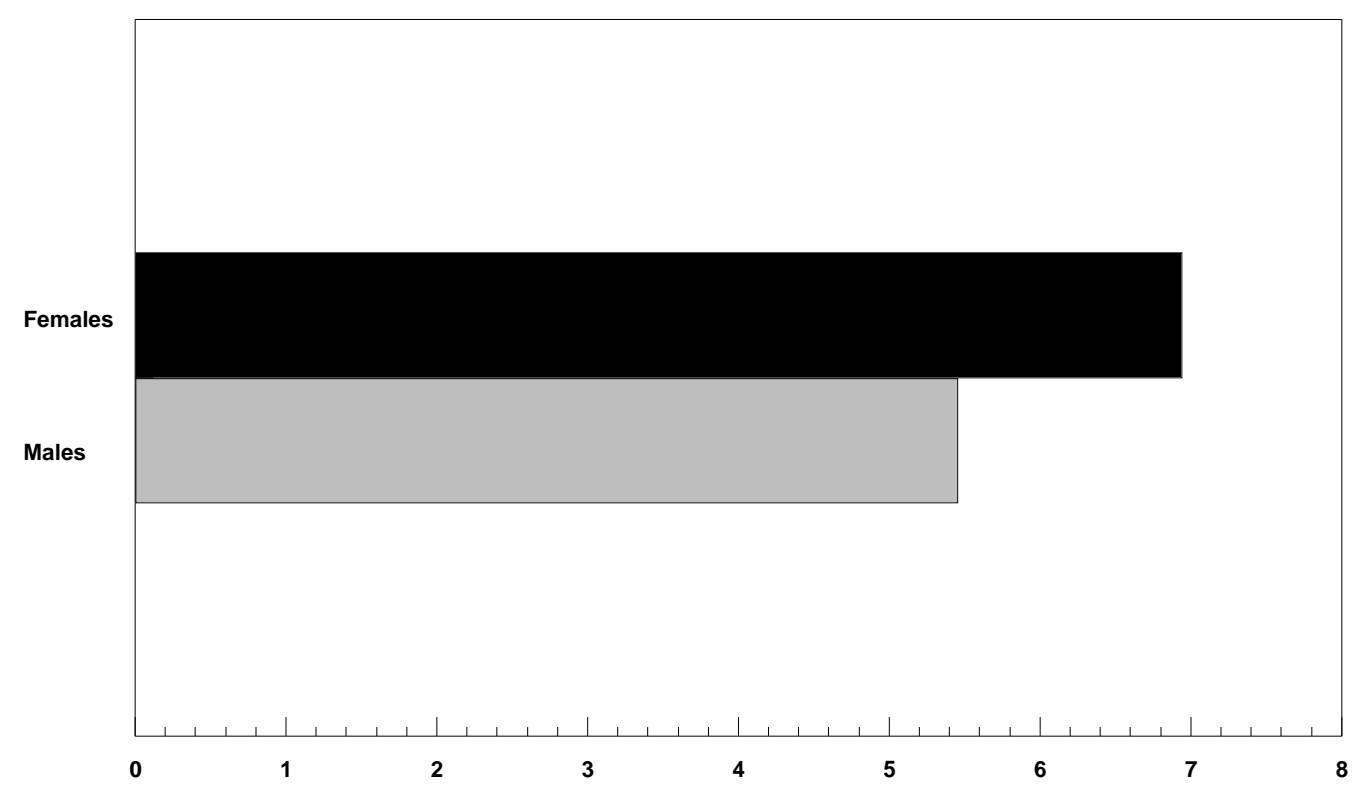




\section{Chart 2}

Paid Work, Unpaid Work and Work of Civic Value by Educational Attainment of Men and Women, 1992
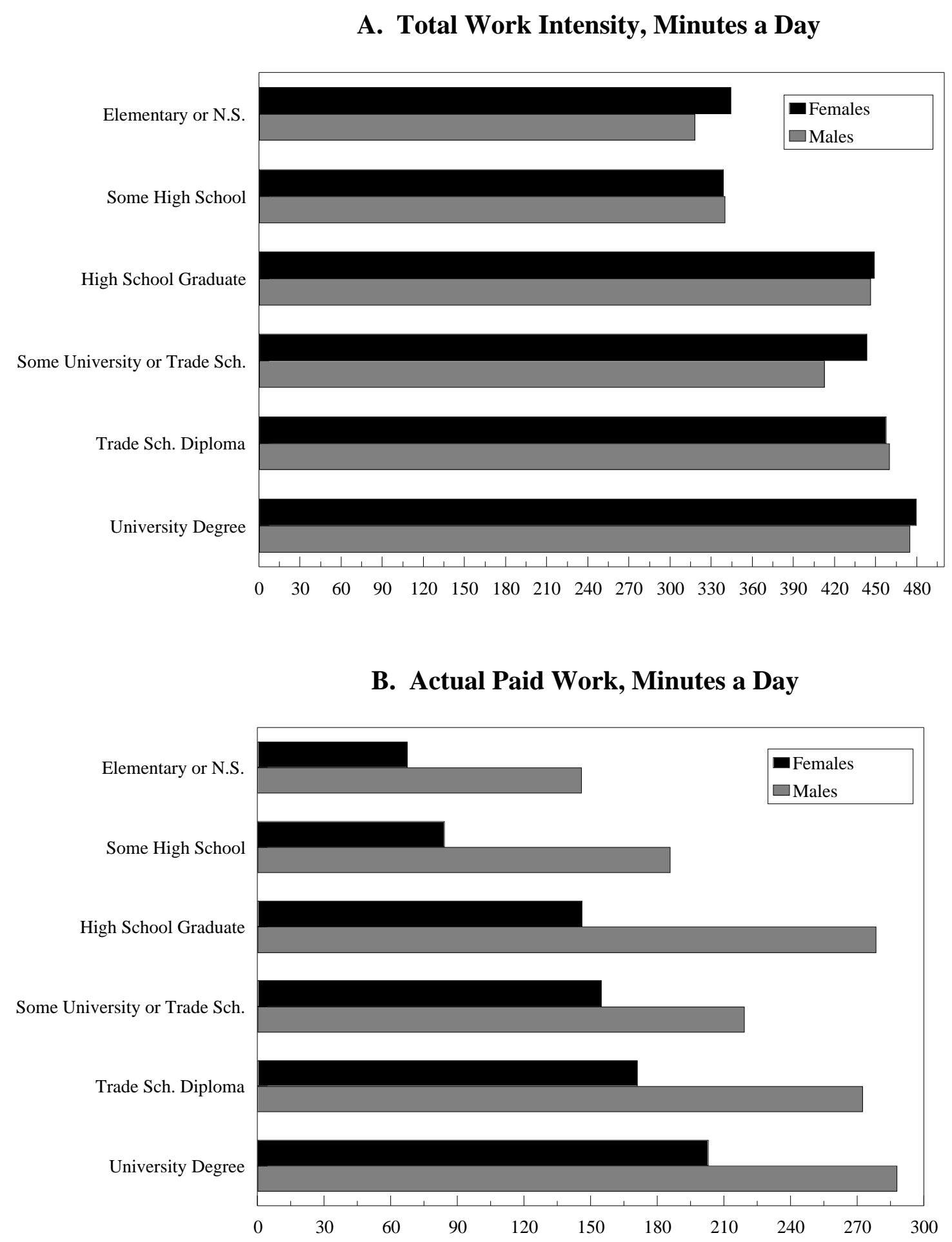


\section{Chart 2}

\section{Paid Work, Unpaid Work and Work of Civic Value by Educational} Attainment of Men and Women, 1992
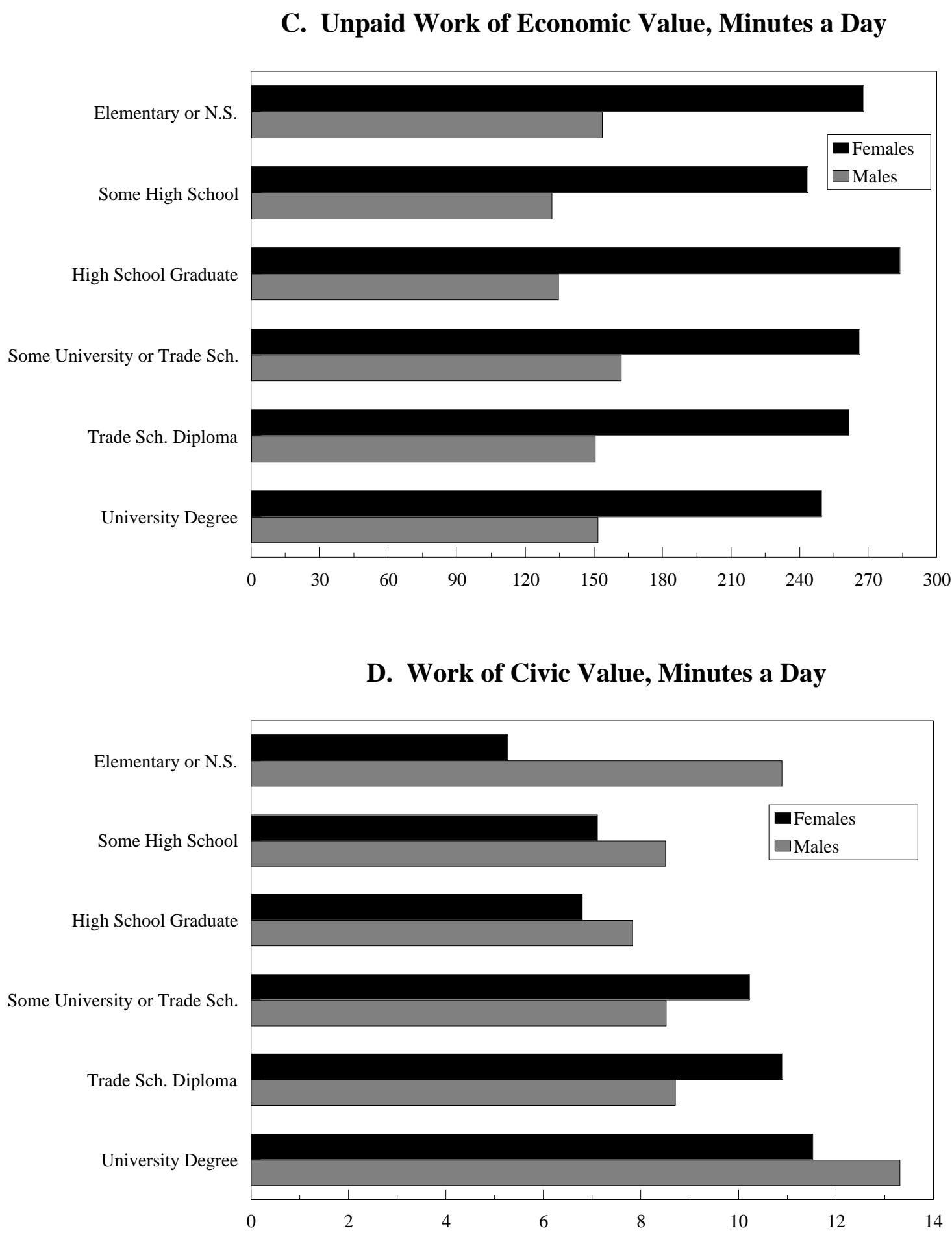


\section{Chart 3}

\section{Leisure and Sleep, by Educational Attainment} of Men and Women, 1992

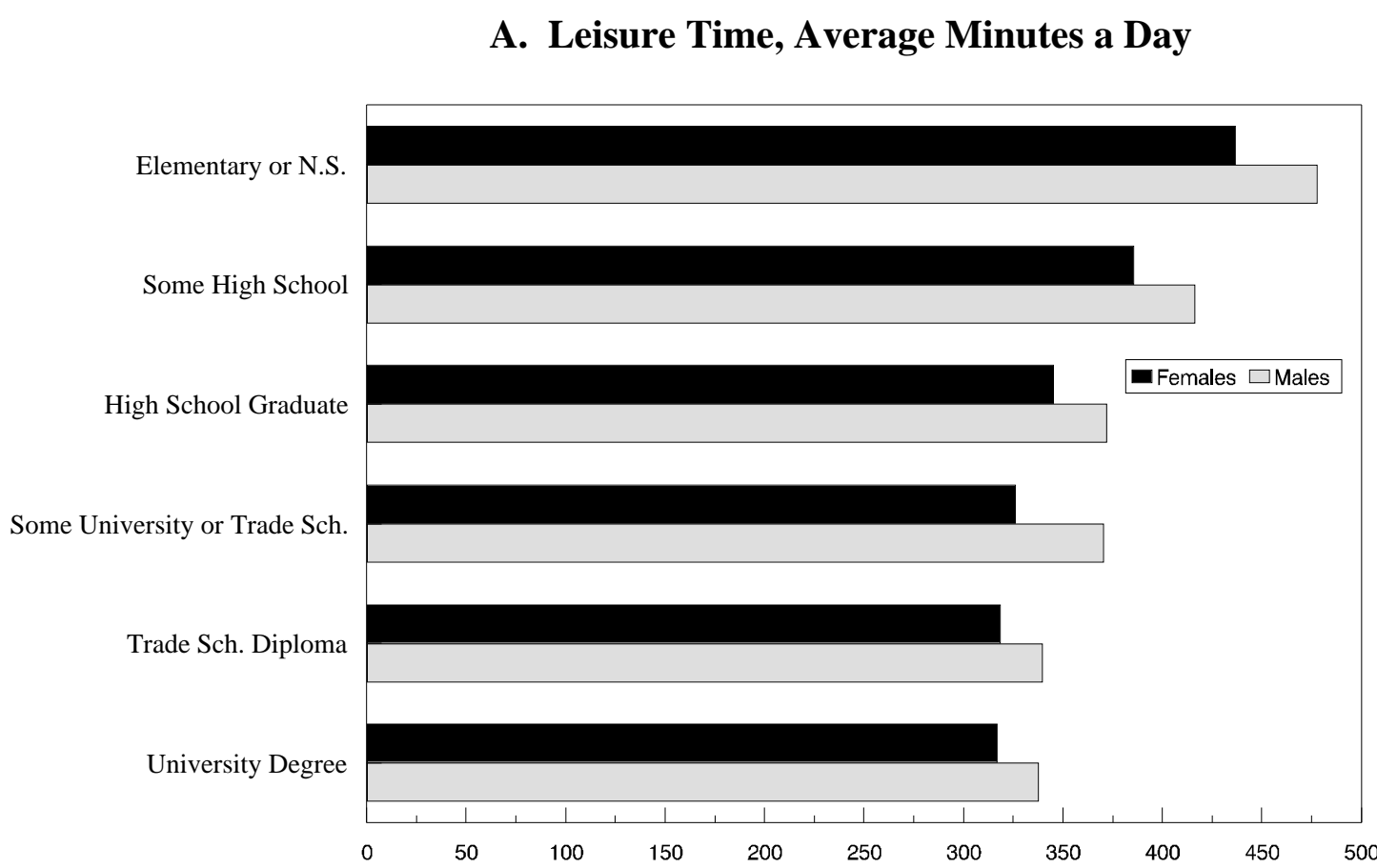

\section{B. Active Leisure Time, Average Minutes a Day}

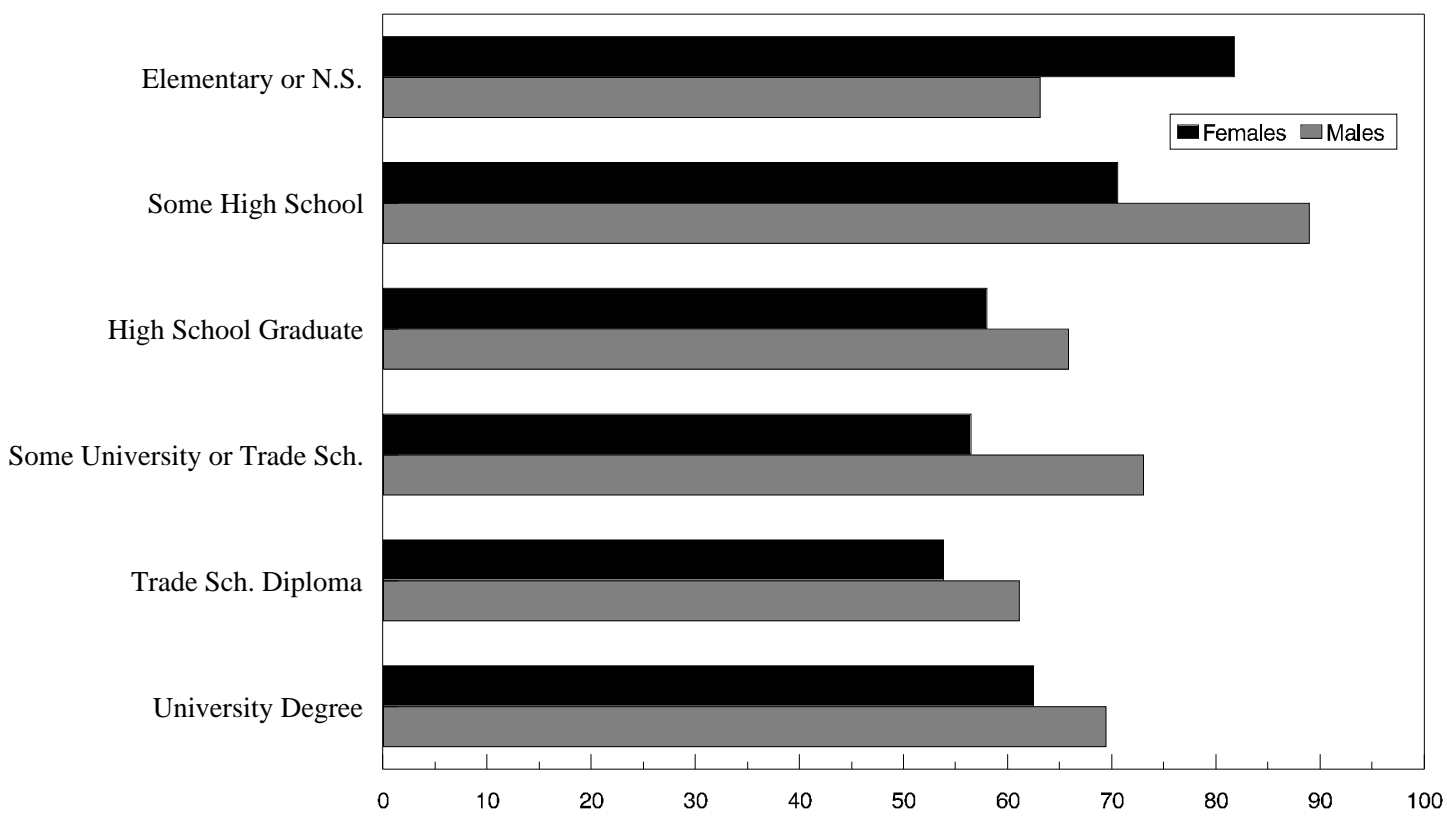




\section{Chart 3}

\section{Leisure and Sleep, by Educational Attainment of Men and Women, 1992}
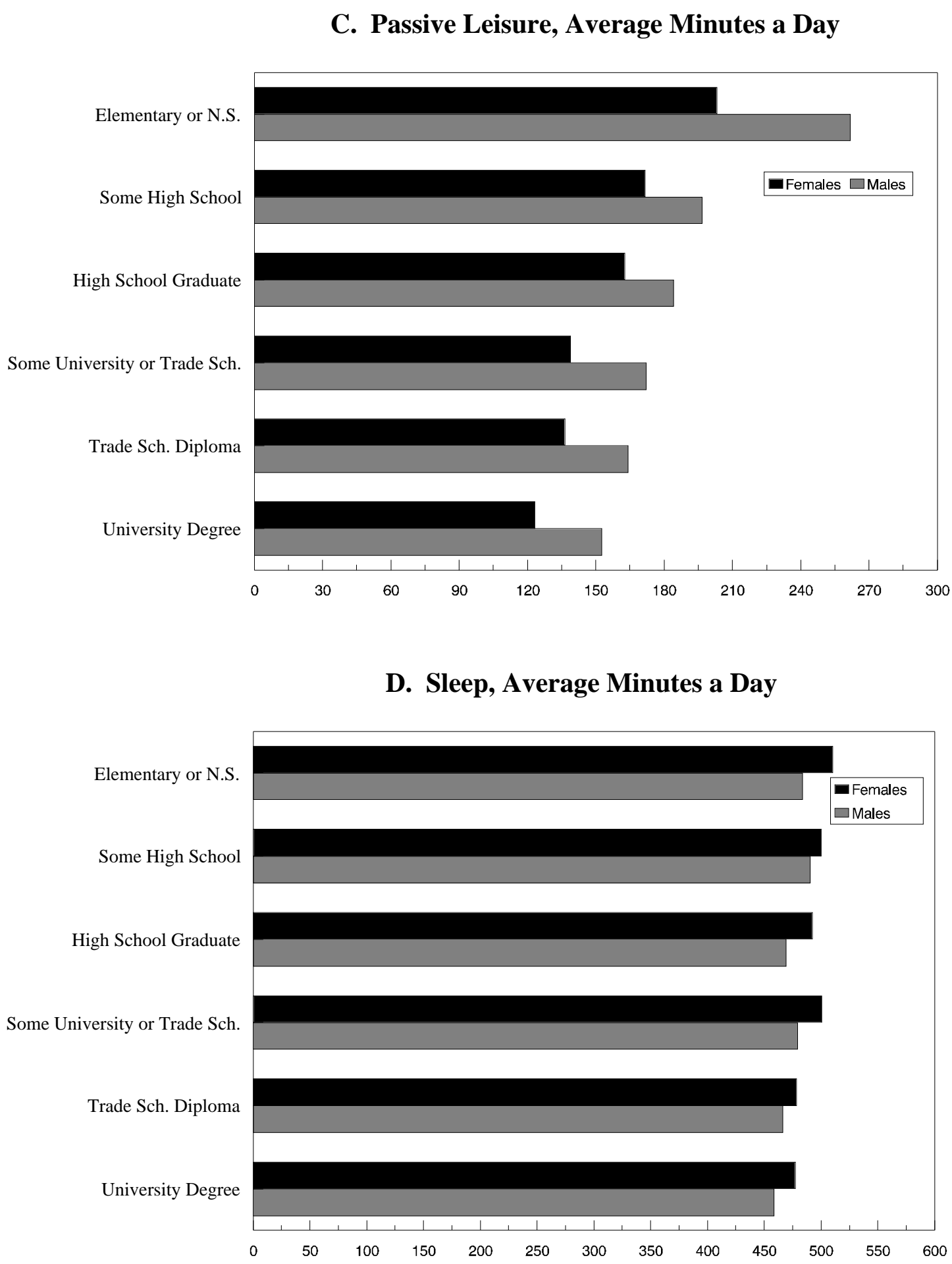


\section{Chart 4}

Work of Civic Value, Child Nurture, Child Care and Other Time with Children, by Education Attainment of Mothers and Fathers, 1992
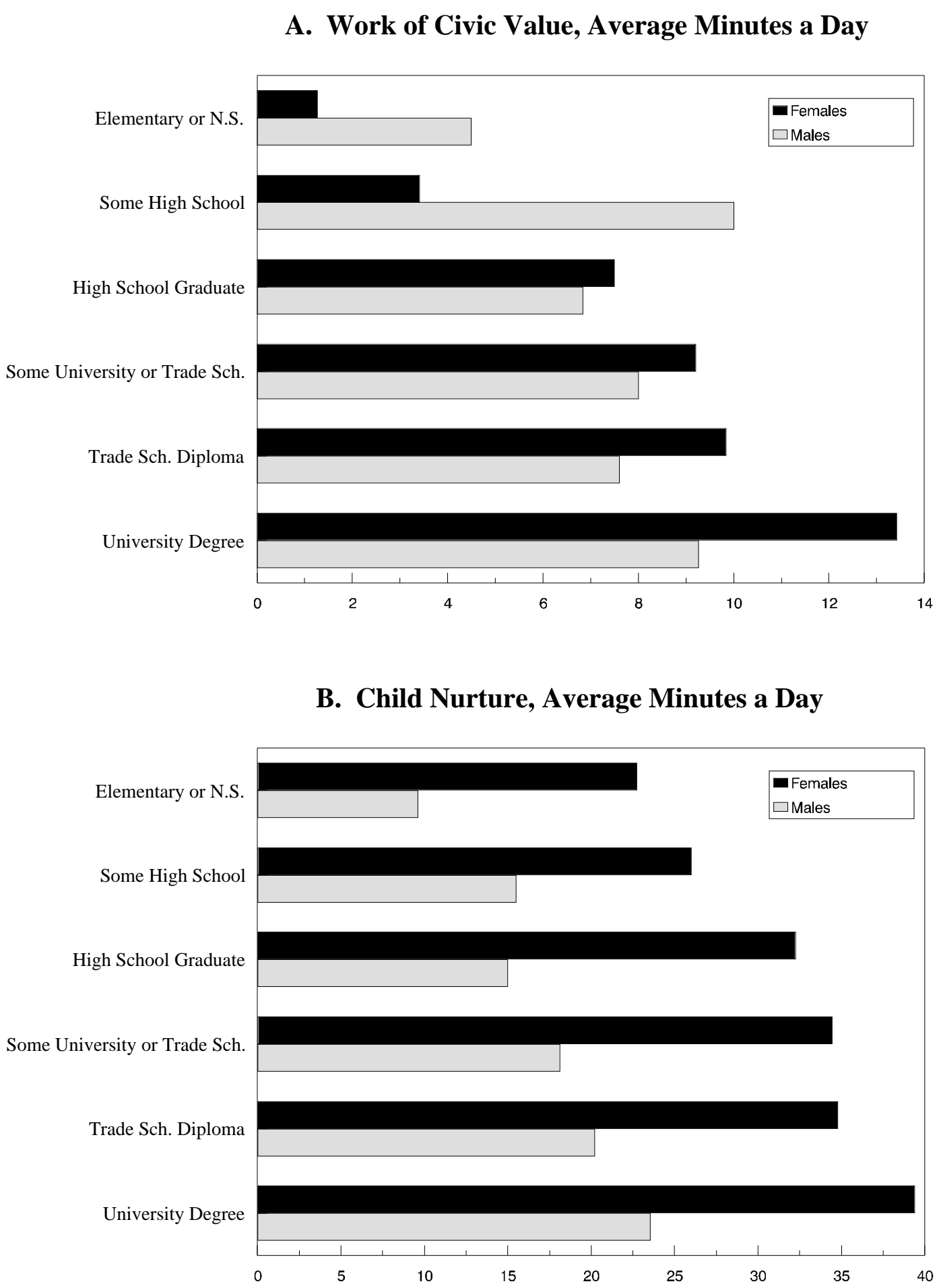


\section{Chart 4}

Work of Civic Value, Child Nurture, Child Care and Other Time with Children, by Education Attainment of Mothers and Fathers, 1992

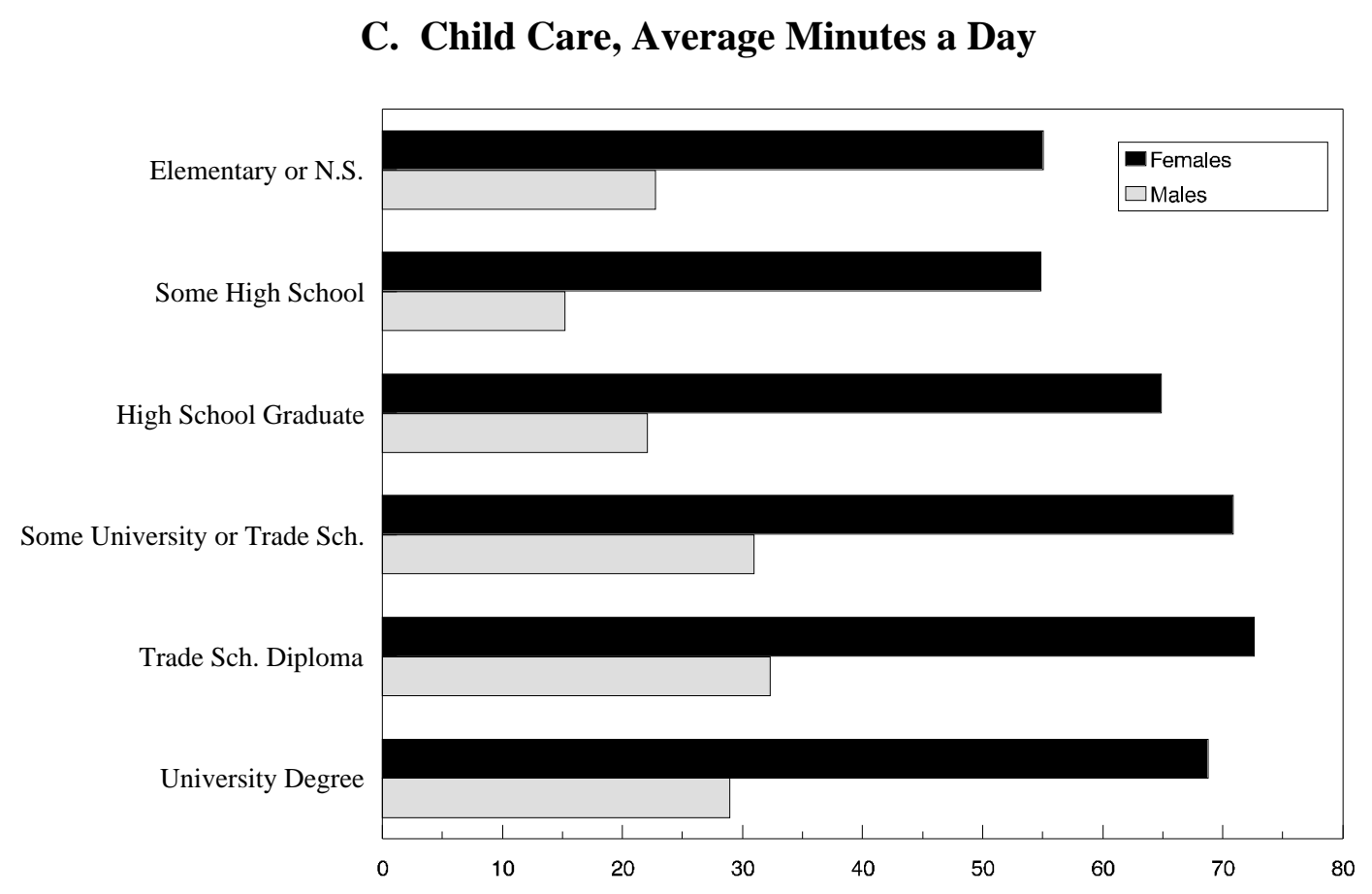

D. Other Time Spent with Children, Average Minutes a Day

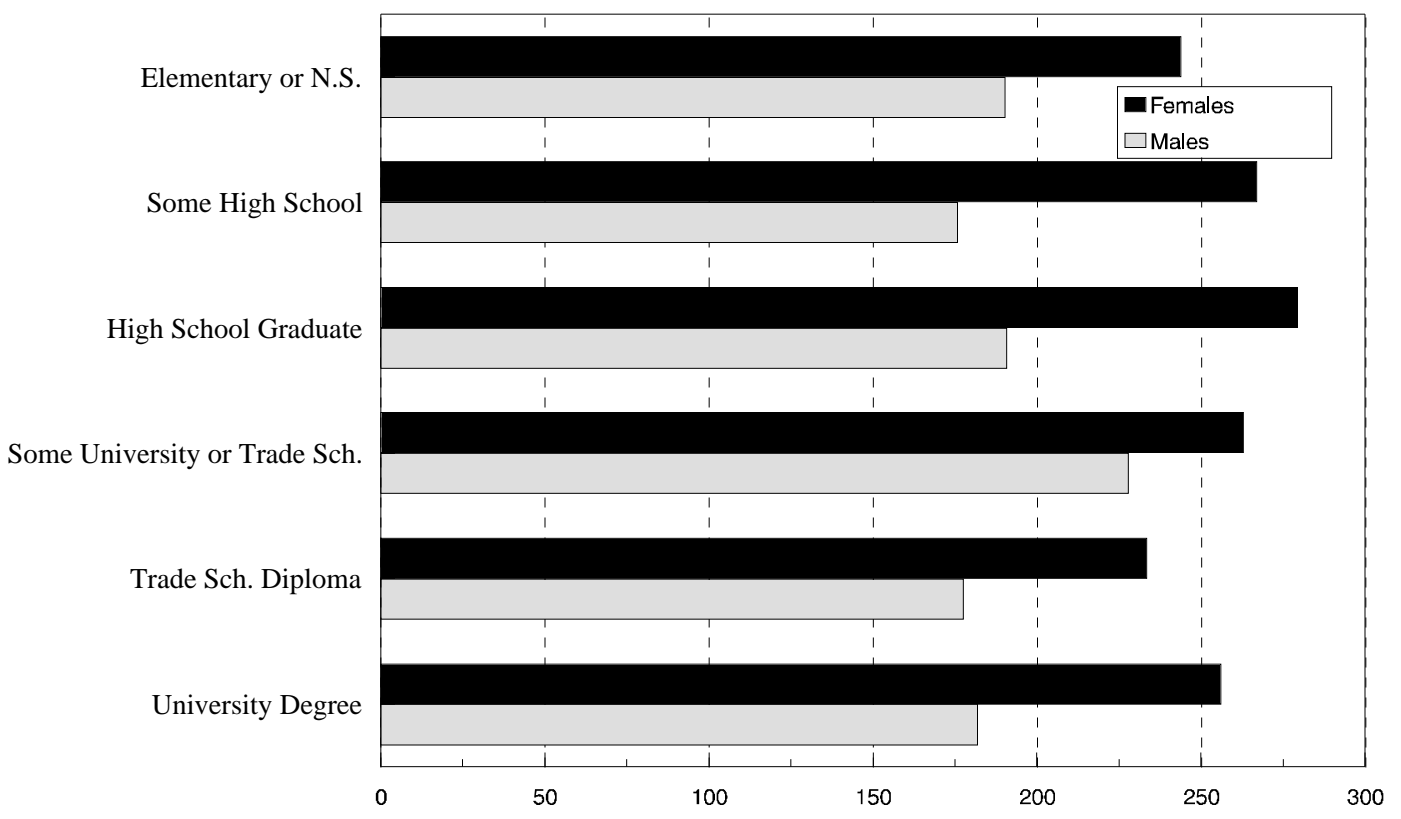




\section{Chart 5}

Paid Work, Unpaid Work and Work of Civic Value by Student Status of Men and Women, 1992

A. Total Work Intensity, Average Minutes a Day

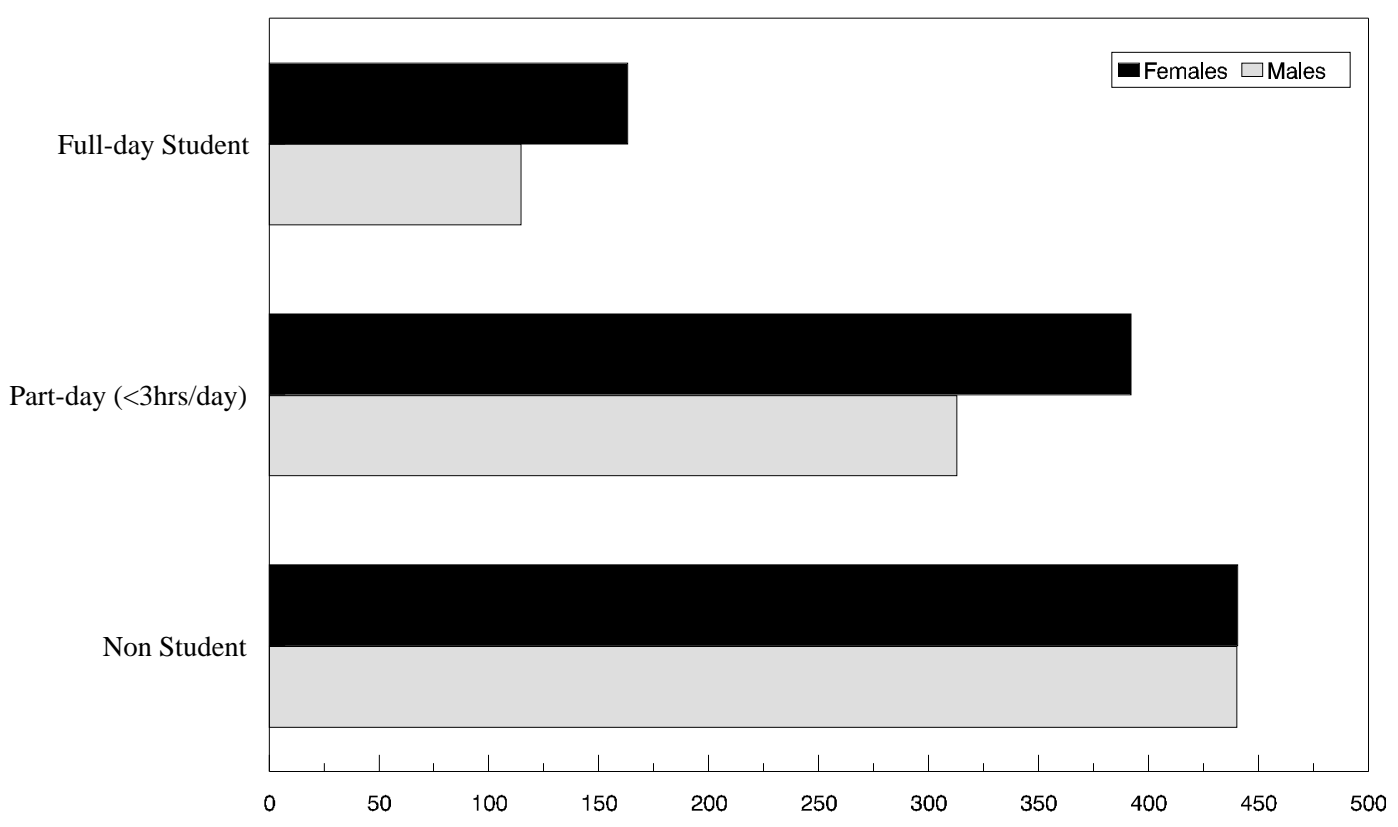

B. Total Work Intensity, Average Minutes a Day

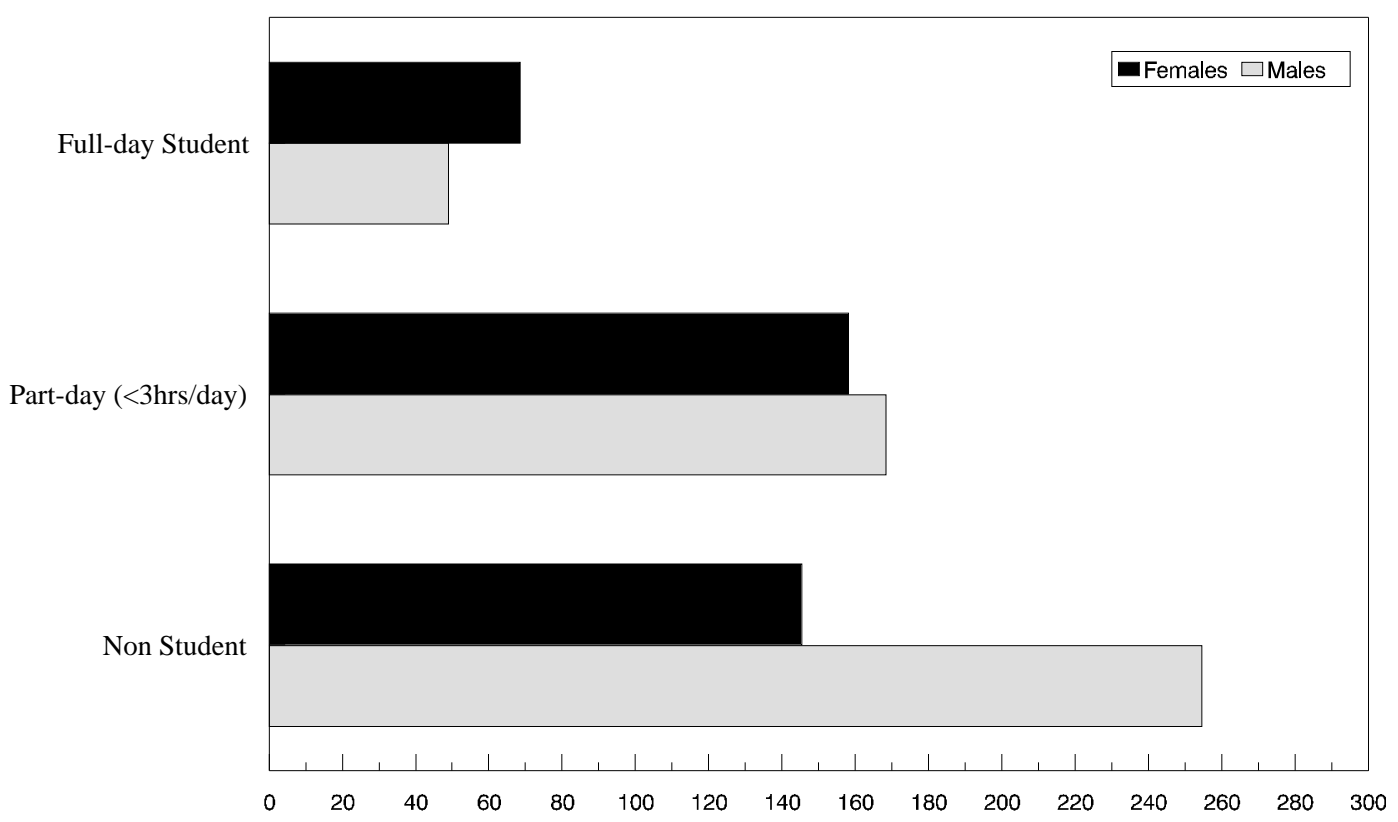




\section{Chart 5}

Paid Work, Unpaid Work and Work of Civic Value by Student Status of Men and Women, 1992

C. Unpaid Work of Economic Value, Average Minutes a Day

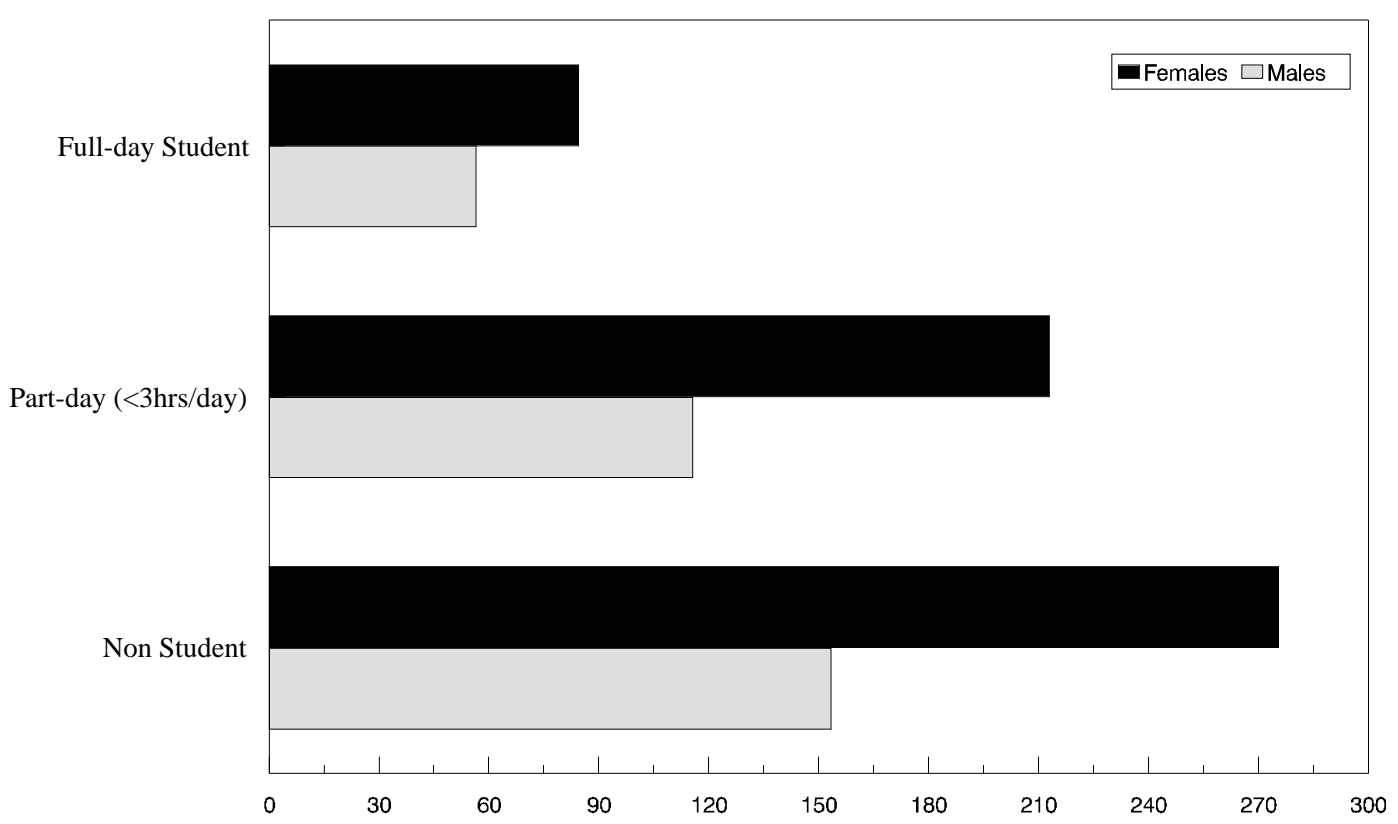

D. Work of Civic Value, Average Minutes a Day

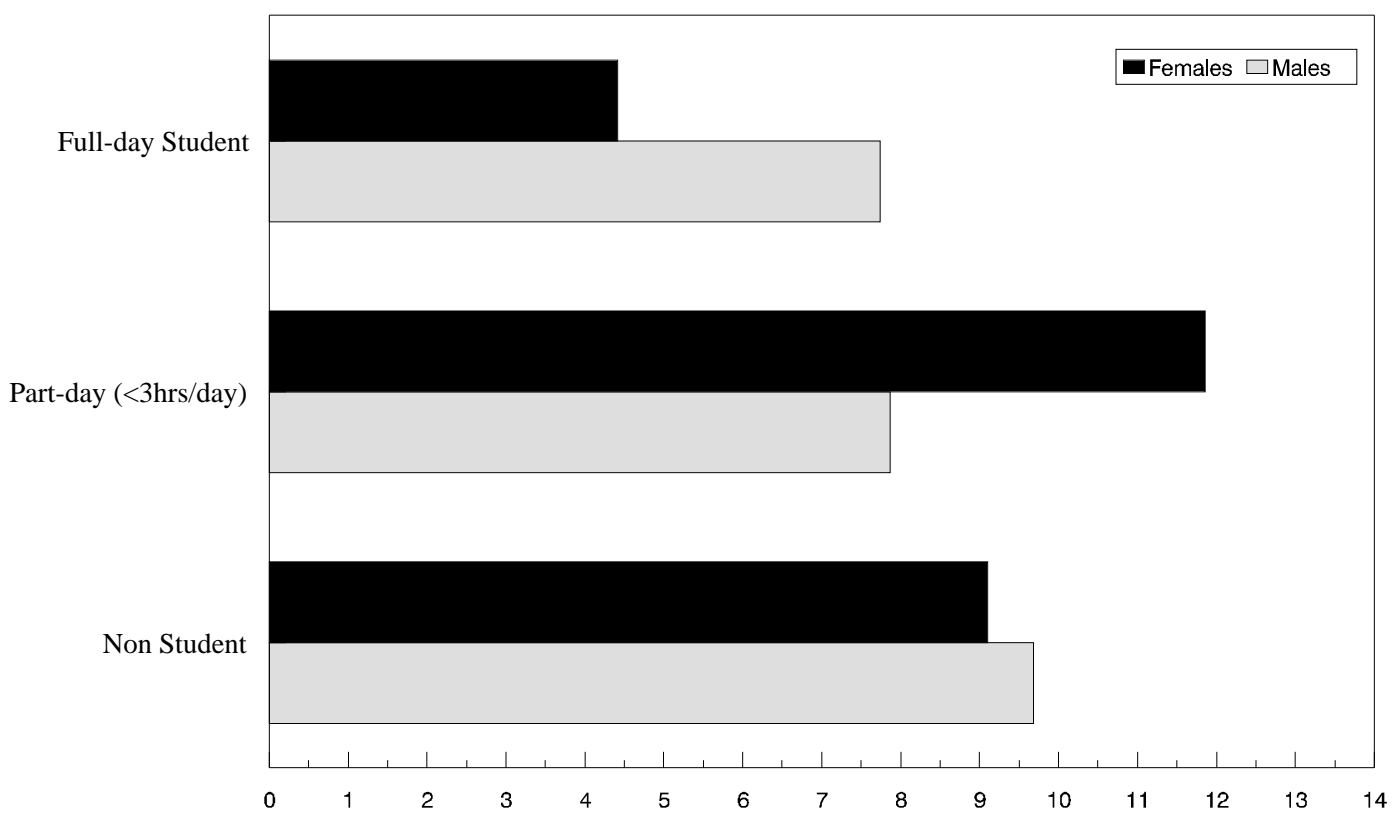




\section{Chart 5}

Paid Work, Unpaid Work and Work of Civic Value by Student Status of Men and Women, 1992
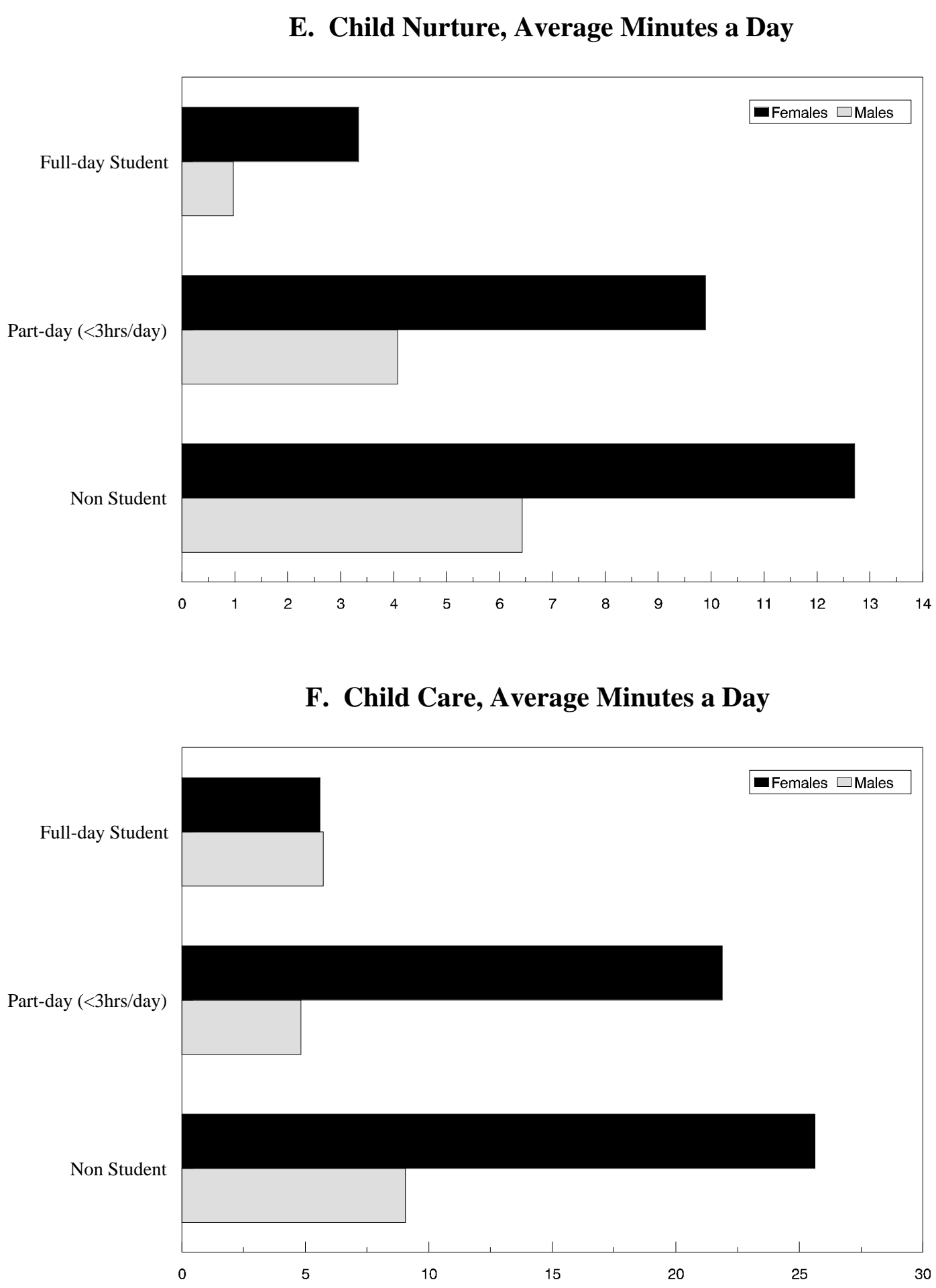


\section{Chart 6 \\ Leisure Time and Sleep, by Student Status of Men and Women, 1992}

\section{A. Leisure Time, Average Minutes a Day}

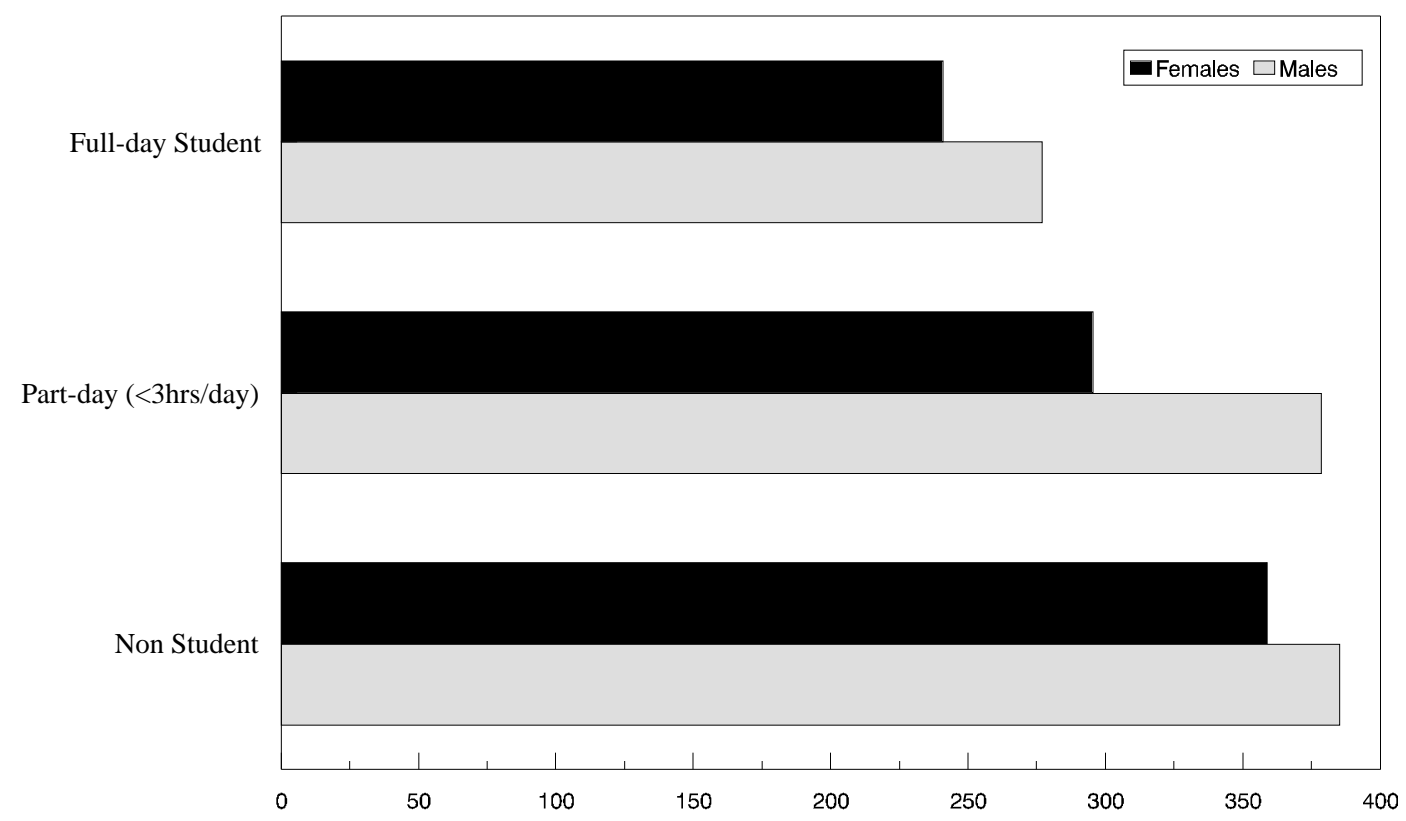

B. Active Leisure Time, Average Minutes a Day

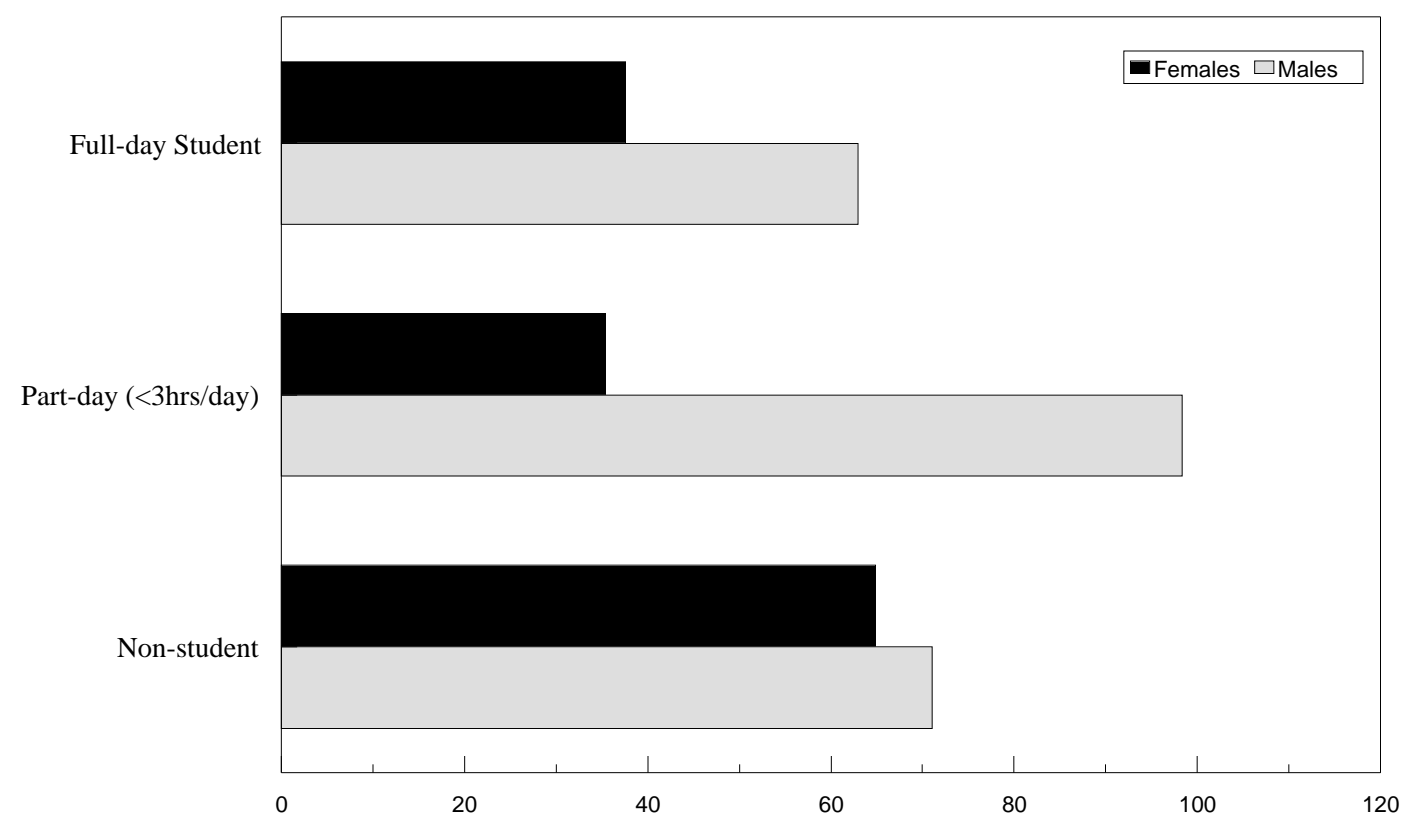




\section{Chart 6 \\ Leisure Time and Sleep, by Student Status of Men and Women, 1992}

C. Passive Leisure Time, Average Minutes a Day

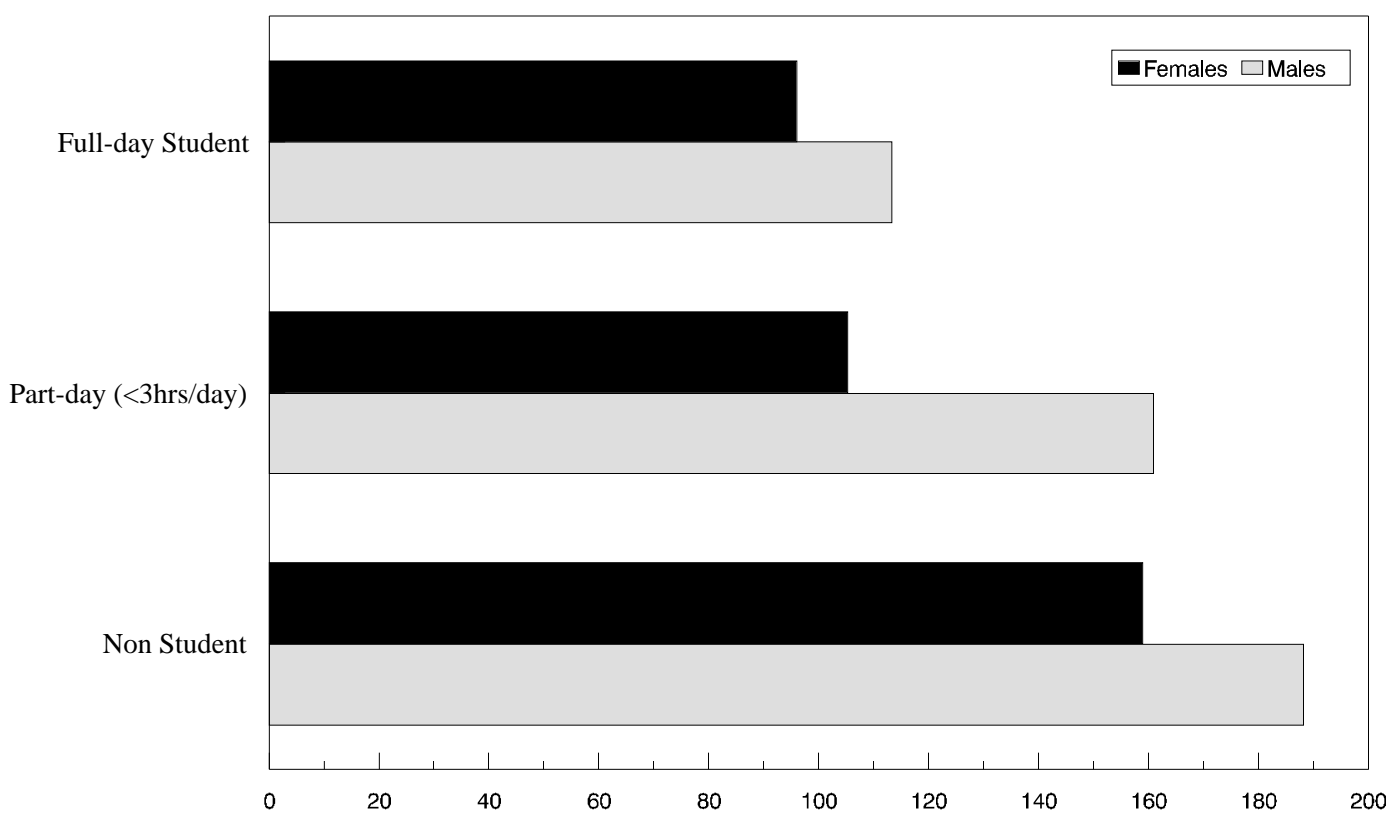

D. Sleep, Average Minutes a Day

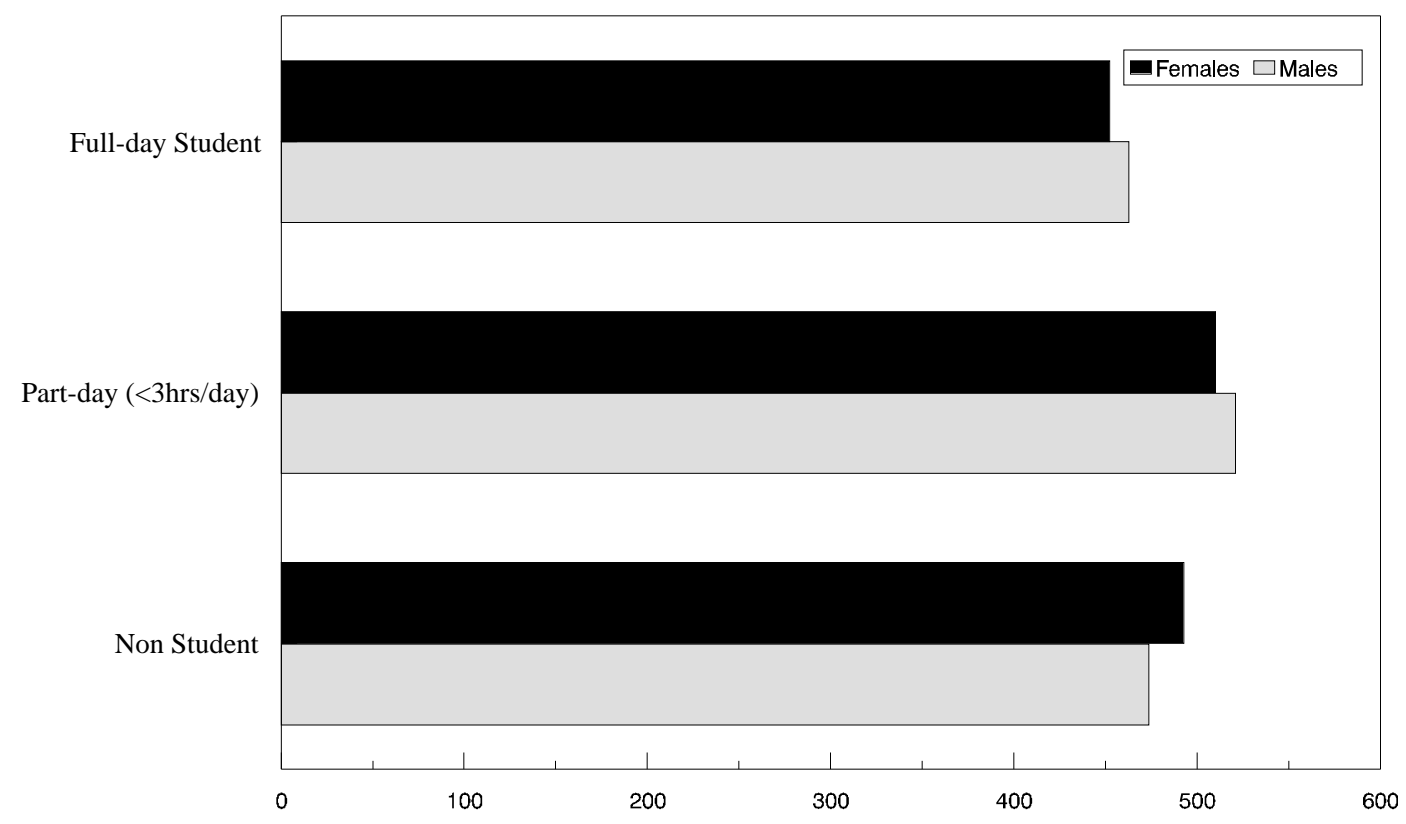




\section{Chart 6 \\ Leisure Time and Sleep, by Student Status of Men and Women, 1992}

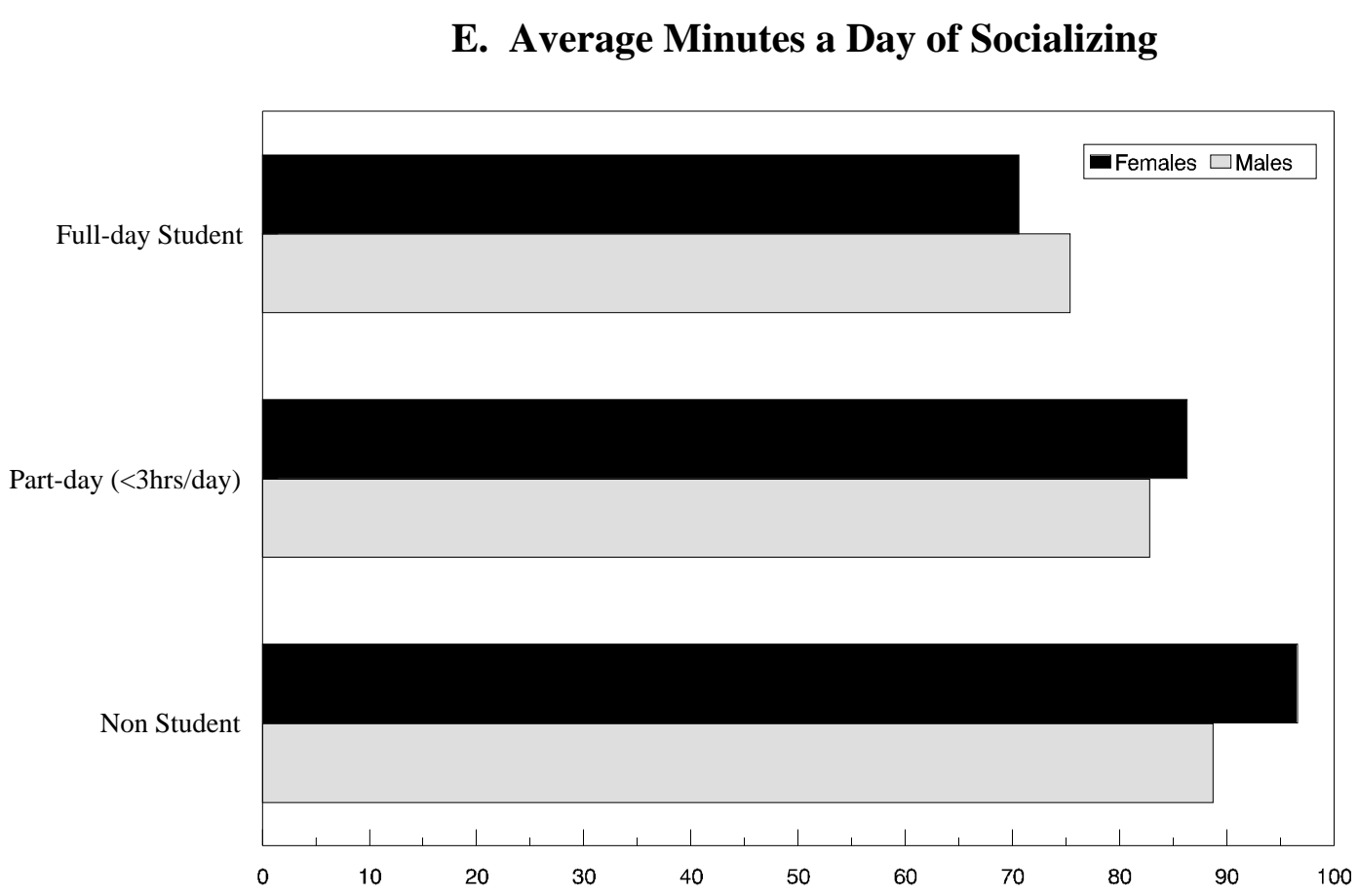

F. Average Minutes a Day of Watching TV or Listening to the Radio, Records or CD's

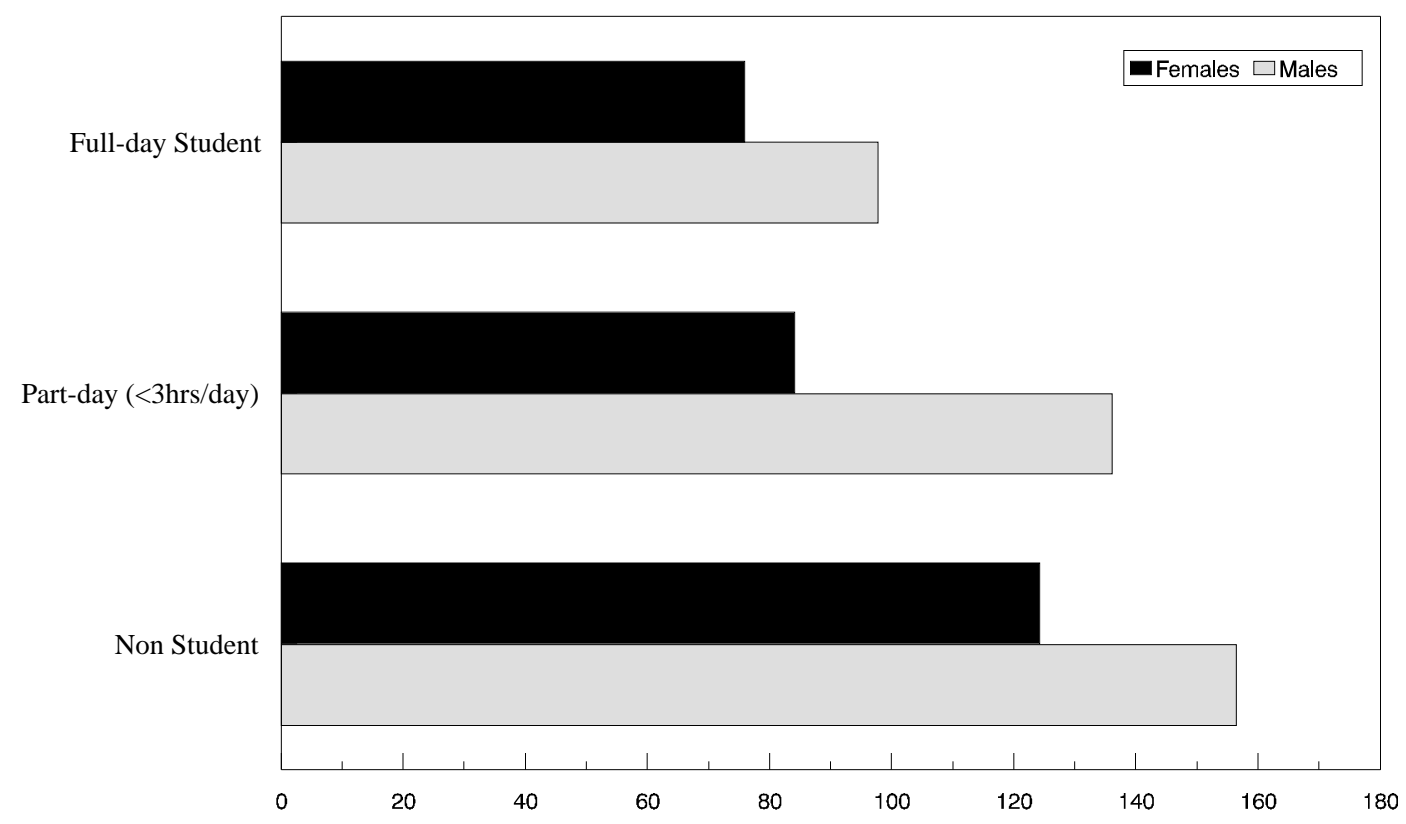




\section{REFERENCES}

Blaug, Mark. "Review of Economics of Education: Research and Studies, edited by George Psacharopoulos, Pergamon Books: Oxford, 1987", in The Journal of Human Resources, XXIV, no.2, Spring, 1989, pp. 331-5.

Bowen, H.R. Investment in Learning: the Individual and Social Value of American Higher Education, Jossey Bass: San Francisco, 1977.

Covey, Stephen R. The Seven Habits of Highly Effective People Simon and Schuster: New York, 1989.

Gullason, Edward T. "The Consumption Value of Schooling: An Empirical Estimate of One Aspect," Journal of Human Resources, XXIV, 2, pp. 287-98, Spring, 1989.

Hanushek, E. A. "Educational Production Functions", In George Psacharopoulos, ed., Economics of Education: Research and Studies, 1987, pp. 33-42.

Haveman, Robert H., and Barbara L. Wolfe, "Schooling and Economic Well-Being: The Role of Nonmarket Effects", Journal of Human Resources, XIX, no. 3, Summer, 1984, pp. 377-407.

Hill, C. Russell, and Frank P. Stafford, "Parental Care of Children: Time Diary Estimates of Quantity, Predictability, and Variety", in F. Thomas Juster and Frank P. Stafford, eds., Time, Goods and Well-Being University of Michigan: Ann Arbor, 1985, pp. 415-437.

F. Thomas Juster, "Investment of Time by Men and Women", in F. Thomas Juster and Frank P. Stafford, eds., Time, Goods and Well-Being University of Michigan: Ann Arbor, 1985, pp. 177-204.

Leibowitz, Arleen. "Human Investments in Children"Journal of Political Economy, MarchApril, 1974, pp. S111-S131.

Lockheed, M. E. "Farmer's Education and Economic Performance," in G. Psacharopoulos, ed., Economics of Education: Research and Studies, 1987, pp. 110-116.

Machlup, F. "Knowledge Industries and Knowledge Occupations," in George Psacharopoulos, ed., Economics of Education: Research and Studies, 1987, pp. 14-21.

Psacharopoulos, George, ed. Economics of Education: Research and Studies, Pergamon Books: Oxford, 1987.

Solmon, L. C. "The Range of Educational Benefits", in George Psacharopoulos, ed., Economics of Education: Research and Studies, Pergamon Books: Oxford, 1987, pp. 83-93. 
Stone, Leroy O., Marie-Therese Chicha and Frank Jones, Design of the Statistics Canada Total Work Accounts System, paper presented to the 23rd conference of the International Association for Research on Income and Wealth, St. Andrews, New Brunswick, Canada, August 21 to 27, 1994.

Woodall, W. "Economics of Education: A Review", in George Psacharopoulos,Economics of Education: Research and Studies, 1987, pp. 1-8. 